\title{
ВМІСТ КРОХМАЛЮ У ЗЕРНІ КУКУРУДЗИ ТА ВИХІД БІОЕТАНОЛУ ЗАЛЕЖНО ВІД УМОВ ВЕГЕТАЦІЇ ТА ФАКТОРІВ ТЕХНОЛОГІЇ ВИРОЩУВАННЯ
}

\author{
ПАЛАМАРЧУК В.Д. - доктор сільськогосподарських наук, доцент \\ https://orcid.org/0000-0002-4906-3761 \\ Вінницький національний аграрний університет \\ BIHHIK O.В. - аспірант \\ https://orcid.org/0000-0003-0175-4544 \\ Вінницький національний аграрний університет \\ КОВАЛЕНКО О.А. - кандидат сільськогосподарських наук, доцент \\ https://orcid.org/0000-0002-2724-3614 \\ Миколаївський національний аграрний університет
}

Постановка проблеми. В умовах дефіциту енергоносіїв та зростання цін на них в Україні, значну частку яких Україна імпортує, одним із резервів енергетичної незалежності країни $є$ пошук резервів виробництва альтернативних видів енергії. Одним із таких видів енергії за умови підвищення урожайності $€$ виробництво із зерна кукурудзи біоетанолу. Потенційні можливості цього напряму величезні: тільки завдяки переробці 10 млн. т кукурудзи Україна може виробляти не менше 4 млн. т цього біопалива. Впродовж останнього півстоліття посівні площі під кукурудзою зросли в 1,6 рази, врожайність - у 3 рази, а валові збори зерна - в 4,8 рази [1-3]. Вирощування кукурудзи разом із продовольчим та кормовим нині асоціюється з новим напрямом використання, таким як переробка на біоетанол, оскільки зерно кукурудзи має високий вміст крохмалю (60-85\%). Крохмаль, який міститься в зерні, спочатку розкладається до цукру, потім цей цукор у процесі бродіння перетворюється на алкоголь, після чого розчин піддають очищенню та випаровуванню [4].

Аналіз останніх досліджень і публікацій. У США близько 40\% урожаю кукурудзи (130 млн. т на рік) перероблюються для отримання кукурудзяного етанолу [5]. Отриманий біоетанол ефективно використовують як компонент високооктанового бензину. Порівняно з іншими культурами кукурудза має великий вміст крохмалю в зерні та забезпечує найвищий рівень отримання біоетанолу з гектара [6]. 3 однієї тони зерна кукурудзи можна отримати 325-470 л етанолу, тоді як з 1 т ячменю - 240-330, жита - 280-357, пшениці - 375-445 л [4], тритикале - 428 л, соризу - 464 л. Хоча сориз має більший вміст крохмалю у зерні, його важче гідролізувати, тому вихід біоетанолу з кукурудзи більший [7]. Для виробництва 1,0 т біоетанолу необхідно 0,64 га пшениці або 0,47 га кукурудзи [4].

Сумарна виробнича потужність біоетанолу в Україні може становити близько 200 тис. т на рік (5\% від усіх видів палива), але у 2013-2014 роках виробництво його було практично знищене (до 42 тис. т на рік у 2016 році, тобто близько 1\% всього палива) введенням акцизу у межах 99 євро на альтернативні моторні палива, що становить 49\% від акцизу на бензин А-95. Така акцизна ставка призвела до зупинки 11 з 14 заводів, які виробляли біоетанол. Державою планується зняти акциз на виробництво біоетанолу та звільнити від ПДВ під час
Таблиця 1 - Орієнтовна урожайність різних сільськогосподарських культур та можливий вихід біоетанолу з біосировини [8]

\begin{tabular}{|l|c|c|c|}
\hline \multirow{2}{*}{$\begin{array}{c}\text { Культура } \\
\text { (біосировина) }\end{array}$} & $\begin{array}{c}\text { Планова } \\
\text { урожай- } \\
\text { ність, } \\
\text { т/га }\end{array}$ & $\begin{array}{c}\text { Вихід етанолу } \\
\text { 3 тони сиро- } \\
\text { вини, л/т }\end{array}$ & $\begin{array}{c}\text { на один } \\
\text { гектар, л/га }\end{array}$ \\
\hline Цукровий буряк & 90 & 100 & 9000 \\
\hline Топінамбур & 30 & 87 & 2610 \\
\hline $\begin{array}{l}\text { Кукурудза } \\
\text { на зерно }\end{array}$ & 7 & 416 & 2912 \\
\hline Сорго цукрове & 80 & 50 & 4000 \\
\hline Пшениця & 5 & 395 & 1975 \\
\hline Ячмінь & 5,8 & 370 & 2150 \\
\hline $\begin{array}{l}\text { Цукрова } \\
\text { тростина }\end{array}$ & 65 & 70 & 4550 \\
\hline Кассава (маніок) & 12 & 180 & 2160 \\
\hline
\end{tabular}

закупівлі імпортної техніки, обладнання, устаткування підприємств з виробництва біопалива [9].

Ціна продажу біоетанолу у 2019 році в Україні становить 0,61 євро/л, в Європі - 0,96 євро/л [10], тоді як бензину 1,2-1,6 євро/л. У зв'язку з цим великого значення у виробничій сфері набуває оцінювання сучасних гібридів кукурудзи за придатністю використання їх зерна для виробництва біоетанолу [11; 12]. У зерні кукурудзи переважаючими компонентами $€$ вуглеводи (крохмаль, цукри, клітковина, геміцелюлоза та пентозани), вміст яких може становити залежно від підвиду 60-80\%. Для отримання етанолу практичну цінність мають чотири підвиди кукурудзи, а саме крохмалистий $(71,5-82,0 \%)$, зубовидний $(68,0-75,5 \%)$, напівзубовидний $(66,9-74,2 \%)$ і кременистий $(65,0-73,0 \%)$ [13].

За даними Я.М. Гадзало, у 2018 році створені гібриди кукурудзи зі врожайністю 8,14 т/га, виходом крохмалю з 1 га у 6 т. За його словами, одним із найперспективніших напрямів селекції кукурудзи $€$ створення сортів із високим вмістом крохмалю для виробництва біоетанолу [14].

Вміст крохмалю в зерні залежить як від сортових особливостей, так і від технології вирощування кукурудзи на зерно, тому розроблення комплексу елементів технології, що забезпечують збільшення урожайності та якості зерна кукурудзи, $є$ актуальним. 
Мета статті полягає у вивченні впливу кліматичних умов та елементів технології на продуктивність, якість зерна та вихід біоетанолу в гібридів кукурудзи різних груп стиглості.

Матеріали та методика досліджень. Польові досліди проводились протягом 2011-2016 років на дослідному полі кафедри рослинництва, селекції та біоенергетичних культур ДП ДГ «Корделівське» Інституту картоплярства НААН Вінницького національного аграрного університету.

Ґрунти - чорноземи глибокі середньо суглинкові на лесі. Вміст гумусу (за Тюріним) в орному шарі складав 4,60\%. Реакція ґрунтового розчину мала $\mathrm{pH}$ (сольове) 5,7. У ґрунтах містяться легкогідролізований азот (за Корнфілдом) 106 мг на 1 кг ґрунту, рухомий фосфор та обмінний калій (за Чиріковим) 186 і 160 мг на 1 кг ґрунту відповідно. Вміст мікроелементів цих ґрунтів $€$ таким: вміст бору (Калориметричний аналіз) високий (0,76 мг на 1 кг ґрунту); марганцю, міді та цинку (Атомноадсорбційно спектрофотометричний аналіз) також високий $(77,17,6,07$ та 8,01 мг на 1 кг ґрунту відповідно).

Згідно з даними агрометеорологічних спостережень, основні показники кліматичних умов у роки проведення досліджень не були близькими до середніх багаторічних даних. У 2011 році спочатку холодна із заморозками погода у першій-другій декаді квітня обмежувала застосування першого (раннього) строку сівби, тому він був проведений 25 квітня. В подальшому кліматичні умови 2011 року мало відрізнялись від багаторічних і були сприятливими для росту й розвитку кукурудзи. Рання весна 2012 року та високі температури квітня $\left(5,4-16,3^{\circ} \mathrm{C}\right)$ створили несприятливі агрокліматичні умови для розвитку кукурудзи. Так, із травня до другої декади серпня спостерігався дефріцит вологи, про що свідчить суттєве відхилення кількості опадів (207 мм) за цей період від середньо-багаторічних (297 мм). У 2013 році мала кількість температурних показників обмежувала застосування раннього терміну сівби, особливо в першій декаді квітня $\left(3,0^{\circ} \mathrm{C}\right)$. В подальшому кліматичні умови 2013 року мало відрізнялись від багаторічних і були сприятливими для росту й розвитку кукурудзи. У 2014 році негативним явищем були заморозки 5-6 травня. В окремих районах було пошкодження ранніх сходів кукурудзи до $30 \%$ від посіяної площі. Умови росту й розвитку кукурудзи в період листоуторення у 2014 році склалися з підвищеним температурним режимом та достатнім волозабезпеченням. У 2015 році погодні умови весняно-літнього періоду відрізнялися значною нерівномірністю розподілу атмосферних опадів за місяцями. Навіть за сприятливого термічного режиму навесні поточного року початок сівби кукурудзи через перезволоження ґрунту провели на 6 днів пізніше за ранні календарні терміни її початку. У 2016 році стрімке наростання тепла та суха погода сприяли підсиханню ґрунту, станом на 10 квітня сума ефективних температур вище $+5{ }^{\circ} \mathrm{C}$ була в межах 85-100 ${ }^{\circ} \mathrm{C}$. Високі максимальні температури до $+35^{\circ} \mathrm{C}$, місцями і вище в другій та третій декадах липня негативно вплинули на тургорність рослин, якість запліднення у кукурудзи. У вересні погодні умови сприяли завершенню вегетації гібридів кукурудзи.
Польові досліди проводились відповіднос до рекомендацій, викладених у «Методиці польових дослідів із кукурудзою» [15]. В дослідах встановлена господарсько-біологічна оцінка гібридів кукурудзи залежно від строку сівби, розмірів фракції та глибини загортання насіння, позакореневих підживлень мікродобривами.

В дослідженнях застосовувались польовий і лабораторний методи вивчення гібридного матеріалу кукурудзи. Облікова площа ділянок для гібридів становила

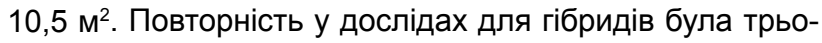
хразовою. Розміщення ділянок відбувалось методом рендомізованих блоків.

Для фрормування фрракції насіння за розмірами зернин використовували решета з круглими отворами різних діаметрів. До великої фракції відносили насіння гібриду сходу решіт з отворами 8 і 9 мм, його частка складала 13,2\% та 13,4\% від загальної маси відповідно. Частки середньої (решета з отворами 6 і 7 мм) фракції складали 71,7-78,8\%, а дрібної (5,0; 5,5 мм) - 7,8-15,1\% [16].

Визначення вмісту крохмалю проводили за допомогою поляриметра А (виробник CARL ZEISSJENA, Німеччина) із точністю 0,1\% згідно з вимогами ДСТУ 46.045:2003 «Зерно. Методи визначення умовної крохмалистості» від 25 липня 2003 року № 250 [17]. Поляриметричний метод базується на здатності розчинів цукрів обертати площину поляризації поляризованого світла. Вміст крохмалю розраховували за такою формулою:

$$
x=\alpha \times K,
$$

де $x$ - вміст крохмалю у відсотках; $\alpha$ - показник сахариметра, \%; К - коефіцієнт Еверса $(=1,898)[17 ; 18]$.

Вихід біоетанолу із зерна розраховували як вихід етанолу. Вихід етанолу - це його кількість, що отримують із тони вуглеводів у перерахунку на крохмаль. Теоретичний вихід обчислюють за рівнянням спиртного бродіння: $\mathrm{C}_{6} \mathrm{H}_{12} \mathrm{O}_{6}=2 \mathrm{C}_{2} \mathrm{H}_{5} \mathrm{OH}+2 \mathrm{CO}_{2}$. 3і 100 кг гексоз утворюються 51,14 кг безводного етанолу і 48,86 кг діоксину вуглецю. За відносної густоти етанолу $\mathrm{d}^{4}{ }_{20}=0,78927$ його теоретичний вихід становить 64,79 л [19; 20].

Технологія вирощування загальноприйнята за виключенням елементів, які досліджувались. Попередником виступала озима пшениця. Після збирання попередника обробіток ґрунту складався із лущення стерні важкими боронами БДТ-7 та оранки плугом ПНЯ-5-40 в агрегаті із трактором ХТ3-121. Для передпосівного обробітку ґрунту використовували просапний культиватор КПС-4 в агрегаті із зубовими боронами. Сівбу проводили сівалкою СУПН-8 оновленою з нормою висіву 75 тис. шт. насінин на гектар.

В дослідженнях використовували гібриди вітчизняної селекції (Харківський 195МВ та Переяславський 230CB) та компанії «Монсанто» DКС 2870, DKC 2960, DKC 2949, DKC 2787, DKC 2971, DKC 3476, DKC 3795, DKC 3472, DKC 3420, DKC 3871, DK 391, DKC 3511, DK 440, DKC 4964, DKC 4626, DK 315, DKC 4082.

У фазі 5 справжніх листків кукурудзи застосовувався післясходовий гербіцид системної дії Мелагро (д. р. нікосульфурон) для боротьби з однорічними і багаторічними злаковими бур'янами у нормі 1,25 л/га. Обприскування дослідних ділянок проводили вранці або ввечері за 
швидкості вітру до 4-5 м/с, не допускаючи знесення препарату, ранцевим оприскувачем.

Система удобрення передбачала внесення лише рядкового удобрення 60 кг у фрізичній вазі аміачної селітри одночасно з посівом. Внесення мікродобрив Росток кукурудза, Еколист Моно Цинк, регулятора росту рослин Вимпел, бактеріального препарату Біомаг проводили у дві фрази 5-7 та 10-12 листків кукурудзи ранцевим оприскувачем із нормою витрати рідини 500 л/га, або 5 л на 1 сотку.

Збирання врожаю проводили вручну 10 качанів, із кожного повторення по яких проводився структурний аналіз та визначення урожайності [15].

Результати досліджень. Вихід біоетанолу залежить перш за все від вмісту крохмалю у зерні, який визначається групою стиглості, підвидом гібриду та агротехнологією вирощування. Так, ранньостиглі гібриди в Лісостеповій зоні України мають невисоку урожайність зерна та вихід крохмалю, хоча в деяких із них вміст крохмалю в зерні високий. Вищий вміст крохмалю у середньоранніх та середньостиглих гібридів, це можна пояснити тим, що вони представлені зубовидним підвидом, у зерні якого міститься більше крохмалю [7].
Вміст та вихід крохмалю суттєво залежали від групи стиглості гібридів (табл. 2). Так, у середньому за три роки вміст та вихід крохмалю в ранньостиглій групі склали $72,17 \%$ і 5,797 т/га, середньоранній - 73,05\% і 6,576 т/га, середньостиглій - 74,39\% і 7,666 т/га $\left(\mathrm{HIP}_{05 \text { група стиглості }}=0,30 \%\right.$ та 0,16 т/га). Спостерігається зростання вмісту та виходу крохмалю (1,090-1,869 т/га) в групі гібридів кукурудзи з більш тривалим вегетаційним періодом порівняно з ранньостиглою групою, що повністю підтверджується даними літературних джерел.

Найбільший вміст крохмалю $\left(\mathrm{HIP}_{05}\right.$ гібрид $\left.=0,42 \%\right)$ у середньому за три роки відзначено у групі ранньостиглих гібридів: DКС 2870 - 73,51\%, Харківський $195 \mathrm{MB}$ - 72,81\%, DKC 2971 - 72,25\%, середньоранніх: DKC 3420 - 74,43\%, DKC 3476 - 74,38\%, DКС 3795 - 73,19\%, середньостиглих: DКС 4964 76,30\%, DKC 3511 - 75,35\%, DK 440 - 74,39\%, а вихід крохмалю у ранньостиглій групі ( $\mathrm{HIP}_{05 \text { гібрид }}=0,23 \mathrm{~T} /$ га): DKC 2971 - 6,105 т/га, DKC 2960 - 6,026 т/га, DKC 2787 5,933 т/га, середньоранній - DКС 3472 - 7,058 т/га, DKC 3420 - 6,625 т/га, DKC 3476 - 6,613 т/га, а також у середньостиглій - DКС 4964 - 8,147 т/га, DK 315 7,795 т/га, DKC $4626-7,762$ т/га.

Таблиця 2 - Вміст та вихід крохмалю у зерні кукурудзи залежно від строку сівби, \% (середнє за 2011-2013 роки)

\begin{tabular}{|c|c|c|c|c|}
\hline $\begin{array}{c}\text { Група } \\
\text { стиглості } \\
\text { (A) }\end{array}$ & Гібрид (В) & Строки сівби (C) & $\begin{array}{c}\text { Вміст крохмалю } \\
\text { в АCP, \% }\end{array}$ & Вихід крохмалю, т/га \\
\hline 1 & 2 & 3 & 4 & 5 \\
\hline \multirow{18}{*}{ 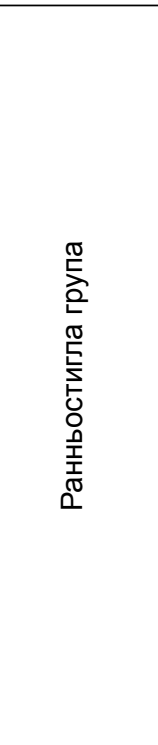 } & \multirow{3}{*}{ Харківський 195МВ } & Ранній $\left(\mathrm{PT}^{*} \mathrm{t}=+8^{\circ} \mathrm{C}\right)$ & 72,00 & 6,288 \\
\hline & & Середній (РТГ t=+10 $\left.{ }^{\circ} \mathrm{C}\right)$ & 72,65 & 5,984 \\
\hline & & Пізній $\left(\right.$ РТГ t=+12 $\left.{ }^{\circ} \mathrm{C}\right)$ & 73,78 & 5,021 \\
\hline & \multirow{3}{*}{ DKC 2870} & Ранній $\left(\mathrm{PT \Gamma}^{*} \mathrm{t}=+8^{\circ} \mathrm{C}\right)$ & 72,74 & 6,499 \\
\hline & & Середній (РТГ t=+10 $\left.{ }^{\circ} \mathrm{C}\right)$ & 73,62 & 5,915 \\
\hline & & Пізній (РТГ t=+12 $\left.{ }^{\circ} \mathrm{C}\right)$ & 74,16 & 4,920 \\
\hline & \multirow{3}{*}{ DKC 2960} & Ранній $\left(\mathrm{PT \Gamma}^{*} \mathrm{t}=+8^{\circ} \mathrm{C}\right)$ & 70,26 & 6,630 \\
\hline & & Середній (РТГ t=+10 ํㅡ) & 72,19 & 6,093 \\
\hline & & Пізній (РТГ t=+12 º $)$ & 72,64 & 5,354 \\
\hline & \multirow{3}{*}{ DKC 2949} & Ранній $\left(\mathrm{PT}^{*} \mathrm{t}=+8^{\circ} \mathrm{C}\right)$ & 70,45 & 5,875 \\
\hline & & Середній (РТГ t=+10 $\left.{ }^{\circ} \mathrm{C}\right)$ & 70,75 & 5,073 \\
\hline & & Пізній (РТГ t=+12 $\left.{ }^{\circ} \mathrm{C}\right)$ & 71,72 & 4,577 \\
\hline & \multirow{3}{*}{ DKC 2787} & Ранній $\left(\mathrm{PT \Gamma}^{*} \mathrm{t}=+8^{\circ} \mathrm{C}\right)$ & 70,61 & 6,379 \\
\hline & & Середній (РТГ t=+10 $\left.{ }^{\circ} \mathrm{C}\right)$ & 71,80 & 5,986 \\
\hline & & Пізній (РТГ t=+12 C) & 72,99 & 5,435 \\
\hline & \multirow{3}{*}{ DKC 2971 (st) } & Ранній $\left(\mathrm{PT \Gamma}^{*} \mathrm{t}=+8{ }^{\circ} \mathrm{C}\right)$ & 71,23 & 6,366 \\
\hline & & Середній (РТГ t=+10 $\left.{ }^{\circ} \mathrm{C}\right)$ & 71,88 & 6,303 \\
\hline & & Пізній (РТГ t=+12 $\left.{ }^{\circ} \mathrm{C}\right)$ & 73,64 & 5,648 \\
\hline \multirow{9}{*}{ 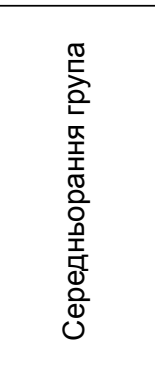 } & \multirow{3}{*}{ DKC 3476} & Ранній $\left(\mathrm{PT}^{*} \mathrm{t}=+8^{\circ} \mathrm{C}\right)$ & 73,38 & 7,124 \\
\hline & & Середній (РТГ t=+10 $\mathrm{C})$ & 74,59 & 6,870 \\
\hline & & Пізній (РТГ t=+12 $\left.{ }^{\circ} \mathrm{C}\right)$ & 75,16 & 5,845 \\
\hline & \multirow{3}{*}{ DKC 3795} & Ранній $\left(\mathrm{PT \Gamma}^{*} \mathrm{t}=+8^{\circ} \mathrm{C}\right)$ & 72,43 & 7,491 \\
\hline & & Середній (РТГ t=+10 $\left.{ }^{\circ} \mathrm{C}\right)$ & 73,12 & 6,493 \\
\hline & & Пізній (РТГ t=+12 $\left.{ }^{\circ} \mathrm{C}\right)$ & 74,02 & 5,365 \\
\hline & \multirow{3}{*}{ DKC 3472} & Ранній $\left(\mathrm{PT \Gamma}^{*} \mathrm{t}=+8^{\circ} \mathrm{C}\right)$ & 70,89 & 7,753 \\
\hline & & Середній (РТГ t=+10 $\mathrm{C})$ & 71,49 & 7,174 \\
\hline & & Пізній (РТГ t=+12 $\left.{ }^{\circ} \mathrm{C}\right)$ & 72,31 & 6,248 \\
\hline
\end{tabular}


Селекція, насінництво

Закінчення таблиці 2

\begin{tabular}{|c|c|c|c|c|}
\hline 1 & 2 & 3 & 4 & 5 \\
\hline \multirow{9}{*}{ 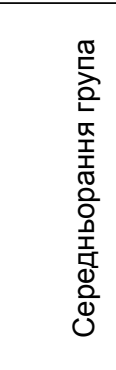 } & \multirow{3}{*}{ DKC 3420} & Ранній $\left(\mathrm{PT}^{*} \mathrm{t}=+8^{\circ} \mathrm{C}\right)$ & 73,31 & 7,558 \\
\hline & & Середній (РТГ t=+10 $\left.{ }^{\circ} \mathrm{C}\right)$ & 74,39 & 6,454 \\
\hline & & Пізній (РТГ t=+12 $\left.{ }^{\circ} \mathrm{C}\right)$ & 75,60 & 5,864 \\
\hline & \multirow{3}{*}{ Переяславський 230СВ } & Ранній $\left(\mathrm{PT \Gamma}^{*} \mathrm{t}=+8^{\circ} \mathrm{C}\right)$ & 71,63 & 7,000 \\
\hline & & Середній (РТГ t=+10 $\left.{ }^{\circ} \mathrm{C}\right)$ & 72,29 & 6,338 \\
\hline & & Пізній $\left(\mathrm{PT} Г \mathrm{t}=+12^{\circ} \mathrm{C}\right)$ & 72,91 & 5,480 \\
\hline & \multirow{3}{*}{ DKC 3871 (st) } & Ранній $\left(\mathrm{PT}^{*} \mathrm{t}=+8^{\circ} \mathrm{C}\right)$ & 71,85 & 7,070 \\
\hline & & Середній (РТГ t=+10 $\left.{ }^{\circ} \mathrm{C}\right)$ & 72,69 & 6,451 \\
\hline & & Пізній (РТГ t=+12 $\left.{ }^{\circ} \mathrm{C}\right)$ & 72,90 & 5,791 \\
\hline \multirow{18}{*}{ 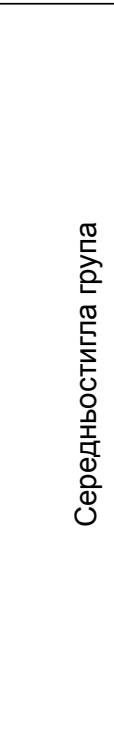 } & \multirow{3}{*}{ DK 391} & Ранній $\left(\mathrm{PT}^{*} \mathrm{t}=+8^{\circ} \mathrm{C}\right)$ & 72,50 & 8,211 \\
\hline & & Середній (РТГ t=+10 $\left.{ }^{\circ} \mathrm{C}\right)$ & 73,21 & 7,080 \\
\hline & & Пізній (РТГ t=+12 $\left.{ }^{\circ} \mathrm{C}\right)$ & 73,30 & 6,650 \\
\hline & \multirow{3}{*}{ DKC 3511} & Ранній $\left(\mathrm{PT \Gamma}^{*} \mathrm{t}=+8^{\circ} \mathrm{C}\right)$ & 74,34 & 7,866 \\
\hline & & Середній (РТГ t=+10 $\mathrm{C})$ & 75,50 & 7,525 \\
\hline & & Пізній (РТГ t=+12 º $)$ & 76,20 & 6,565 \\
\hline & \multirow{3}{*}{ DK 440} & Ранній $\left(\mathrm{PT \Gamma}^{*} \mathrm{t}=+8^{\circ} \mathrm{C}\right)$ & 72,40 & 8,300 \\
\hline & & Середній (РТГ t=+10 $\left.{ }^{\circ} \mathrm{C}\right)$ & 74,95 & 7,620 \\
\hline & & Пізній (РТГ t=+12 $\left.{ }^{\circ} \mathrm{C}\right)$ & 75,84 & 7,054 \\
\hline & \multirow{3}{*}{ DKC 4964} & Ранній $\left(\mathrm{PT \Gamma}^{*} \mathrm{t}=+8^{\circ} \mathrm{C}\right)$ & 74,95 & 8,845 \\
\hline & & Середній (РТГ t=+10 $\mathrm{C})$ & 76,30 & 8,295 \\
\hline & & Пізній (РТГ t=+12 º $)$ & 77,66 & 7,303 \\
\hline & \multirow{3}{*}{ DKC 4626} & Ранній $\left(\mathrm{PT}^{*} \mathrm{t}=+8^{\circ} \mathrm{C}\right)$ & 72,48 & 8,602 \\
\hline & & Середній (РТГ t=+10 $\left.{ }^{\circ} \mathrm{C}\right)$ & 73,49 & 7,642 \\
\hline & & Пізній (РТГ t=+12 $\left.{ }^{\circ} \mathrm{C}\right)$ & 74,10 & 7,041 \\
\hline & \multirow{3}{*}{ DK 315 (st) } & Ранній $\left(\mathrm{PT}^{*} \mathrm{t}=+8^{\circ} \mathrm{C}\right)$ & 73,13 & 8,835 \\
\hline & & Середній (РТГ t=+10 $\left.{ }^{\circ} \mathrm{C}\right)$ & 74,12 & 7,564 \\
\hline & & Пізній (РТГ t=+12 $\left.{ }^{\circ} \mathrm{C}\right)$ & 74,53 & 6,986 \\
\hline \multicolumn{2}{|c|}{$\mathrm{HIP}_{05 \text { група стиглості }}$} & 0,30 & \multicolumn{2}{|l|}{\begin{tabular}{l|l} 
& 0,16 \\
\end{tabular}} \\
\hline \multicolumn{2}{|c|}{$\mathrm{HIP}_{05 \text { гібрид }}$} & 0,42 & \multicolumn{2}{|l|}{0,23} \\
\hline \multicolumn{2}{|c|}{$\mathrm{HIP}_{05 \text { строки сівби }}$} & 0,30 & \multicolumn{2}{|l|}{0,16} \\
\hline
\end{tabular}

* РТГ - рівень температурного режиму ґрунту на глибині загортання насіння

Вміст крохмалю в зерні залежав не лише від групи стиглості гібридів, але й від строків їх сівби. За раннього строку сівби вміст крохмалю найменший, а за пізнього - найбільший. Так, ранній строк сівби $\left(\mathrm{HIP}_{05 \text { строки сівби }}=0,30 \%\right)$ забезпечив вміст крохмалю у ранньостиглих гібридів у 71,22\%, у середньоранніх $72,25 \%$, у середньостиглих $73,30 \%$, застосування середнього строку сівби - 72,15\%, 73,1\% та $74,6 \%$, а пізнього - 73,15\%, 73,82\% та $75,27 \%$ для ранньостиглих, середньоранніх та середньостиглих гібридів відповідно. Проведення сівби у ранні строки $\left(\mathrm{HIP}_{05}\right.$ строк сівби $=0,16$ т/га) за рахунок високої врожайності сприяло найвищому виходу крохмалю $(7,372$ т/га) порівняно із середнім (6,714 т/га) та пізнім (5,953 т/га) строками сівби, тобто застосування пізніх строків сівби сприяло зростанню вмісту та виходу крохмалю на 1,57-1,97\% та 1,181-1,567 т/га відносно раннього строку сівби.

Встановлено, що в посушливий 2012 рік спостерігається загальне зниження вмісту крохмалю (72,06\%) незалежно від строку сівби, тоді як у 2011 та 2013 роках за рахунок сприятливих умов за температурою і вологозабезпеченням відбулося загальне збільшення вмісту крохмалю у кукурудзі до 73,00\% та 74,56\%.

На те, що вміст крохмалю зростає за пізніх строків сівби, вказують у своїх дослідженнях Ю.М. Пащенко та О.І. Кордін [21], при цьому різниця між першим і тре- тім строками сівби за вмістом крохмалю може становити від 0,8\% до 2,0\% за загального його вмісту в зерні $68,0-72,8 \%$.

Дослідженнями встановлено, що вміст крохмалю може істотно змінюватися залежно від підвиду кукурудзи (табл. 3). На цю залежність у своїх дослідженнях вказують інші дослідники [13]

В процесі поділу на підвиди отримано 10 гібридів кременисто-зубовидного підвиду та 8 гібридів зубовидного підвиду. Виявлено, що вміст крохмалю збільшувався від раннього до пізнього строку сівби як у кременисто-зубовидного, так і в зубовидного підвидах кукурудзи. Так, за раннього строку сівби вміст крохмалю становив у кременисто-зубовидного підвиду $71,56 \%$, а в зубовидного - 73,13\%, за середнього строку сівби він складав $72,44 \%$ та $74,21 \%$, а за пізнього - $73,33 \%$ та $75,06 \%$. Аналогічну залежність спостерігали в зубовидного підвиду кукурудзи.

Відзначено вплив позакореневих підживлень мікродобривами Еколист Моно Цинк та Росток кукурудза, бактеріальним препаратом Біомаг та регулятором росту рослин Вимпел на вміст та вихід крохмалю. Такий вплив істотно змінювався залежно від забезпеченості рослин кукурудзи теплом та вологою, про що свідчать результати якісного аналізу зерна щодо вмісту та виходу крохмалю. 
Таблиця 3 - Вміст крохмалю в зерні кукурудзи залежно від підвиду та строку сівби, \% (середнє за 2011-2013 роки)

\begin{tabular}{|c|c|c|c|c|}
\hline \multirow[b]{2}{*}{ Назва підвиду } & \multirow[b]{2}{*}{$\begin{array}{c}\text { Кількість } \\
\text { гібридів, шт. }\end{array}$} & \multicolumn{3}{|c|}{ Строк сівби } \\
\hline & & $\begin{array}{c}\text { ранній } \\
\left(\text { РTГ } \mathrm{t}=+8^{\circ} \mathrm{C}\right)\end{array}$ & $\begin{array}{c}\text { середній } \\
\left(\text { РTГ } \mathrm{t}=+10^{\circ} \mathrm{C}\right)\end{array}$ & $\begin{array}{c}\text { пізній } \\
\left(\mathrm{PT} Г \mathrm{t}=+12^{\circ} \mathrm{C}\right)\end{array}$ \\
\hline Кременисто-зубовидний & 10 & $71,56 \pm 1,06$ & $72,44 \pm 1,11$ & $73,33 \pm 1,01$ \\
\hline Зубовидний & 8 & $73,13 \pm 0,93$ & $74,21 \pm 1,10$ & $75,06 \pm 1,43$ \\
\hline
\end{tabular}

За позакореневих підживлень гібридів ранньостиглої групи істотно збільшувалися вихід крохмалю з одиниці площі на 0,2-1,9 т/га ( IIP $_{05 \text { підживлення }}=0,24$ т/га) та вміст крохмалю порівняно з контролем (підживлення водою).

Найвищий вміст крохмалю та його вихід з одиниці площі забезпечило дворазове позакореневе підживлення всіх гібридів мікродобривом Еколист Моно Цинк.

За позакореневих підживлень у групі ранньостиглих гібридів виявлено незначне зниження вмісту крохмалю $(0,1-0,46 \%)$ за оброблення рослин бактеріальним добривом Біомаг у фазу 5-7 листків кукурудзи порівняно 3 контролем. Найвищий вихід крохмалю (0,6-1,9 т/га) визначено за дворазового позакореневого підживлення мікродобривами Еколист Моно Цинк та Росток кукурудза.

У зерні гібридів кукурудзи середньоранньої групи стиглості вміст крохмалю істотно відрізнявся по гібридах. Проведення позакореневих підживлень забезпечило підвищення вмісту крохмалю та його виходу відносно контролю, а саме підживлення водою $\left(\mathrm{HIP}_{05 \text { підживлення }}=0,65 \%\right.$ та 0,27 т/га), у середньоранніх гібридів на 0,7-1,2\% та 0,2-1,8 т/га.

Одноразове позакореневе підживлення у фразу 5-7 листків кукурудзи забезпечило істотне збільшення вмісту крохмалю по гібридах порівняно 3 контролем, який у середньому за три роки мав такі показники: DKC 3472 - 71,5\%, DKC 3420 - 73,6\%, Переяславський $230 \mathrm{CB}-72,1 \%$, DKC 3871 - 72,5\%, а дворазове підживлення привело до таких наслідків: DКС $3472-72,4 \%$, DKC 3420 - 74,3\%, Переяславський 230CB - 72,1\%, DKC 3871 - 73,5\% (HIP 05 кількість підживлень $=0,41 \%$ ).

Зменшення вмісту крохмалю за позакореневих підживлень відзначено на варіантах, де використовували регулятор росту рослин Вимпел у фразу 5-7 листків кукурудзи у гібриду DKC 3420 на 0,36\%, Переяславський 230 CB на $0,11 \%$ та DKC 3871 на 0,5\% відносно контролю (підживлення водою).

У групі середньостиглих гібридів кукурудзи відзначалося загальне зростання величини вмісту та виходу крохмалю в середньому за роки порівняно з ранньостиглою та середньоранньою групами стиглості.

Проведення позакореневих підживлень забезпечило зростання виходу крохмалю з одиниці площі на 0,2-1,8 т/га ( HIP $_{05 \text { підживлення }}=0,44$ т/га) порівняно з контролем (без позакореневих підживлень). Одноразове позакореневе підживлення забезпечило збільшення вмісту крохмалю на 0,1-0,5\%, дворазове - на 0,85-1,30\%. Найвищий вихід крохмалю у всіх гібридів забезпечило дворазове внесення мікродобрив Еколист Моно Цинк (8,983-10,595 т/га) та Росток кукурудза (8,721-10,597 т/га), зростання виходу крохмалю за застосування цих мікродобрив становило 0,5-1,8 т/га відносно контролю (підживлення водою).

Величина насіння прямо визначає розміри не лише зародка, але й ендосперму, в якому основною запасною речовиною $є$ крохмаль. У зв'язку з цим актуальним питанням залишається те, як буде змінюватися характер формування ендосперму та виходу крохмалю залежно від груп стиглості гібридів, їх сортових особливостей та зміни елементів технології вирощування, а саме фракції насіння та глибини їх загортання (табл. 4).

Вміст та вихід крохмалю в зерні кукурудзи залежали від погодних умов років вегетації. За роками дослідження необхідно відзначити зниження кількості крохмалю у 2015 році на $72,17 \%$ та 6,10 т/га. Вміст та вихід крохмалю в середньому за 2014 рік у досліджуваних гібридів складали $75,46 \%$ та 6,76 т/га, а у 2016 році - 74,58\% та 7,32 т/га. Це пов'язано з тим, що цей рік виявився найменш рівномірно забезпечений вологою з наявністю тривалого посушливого періоду, що, зрештою, вплинуло на нагромадження крохмалю (рис. 1).

Ця залежність підтверджується результатами досліджень інших авторів. Зокрема, дослідження А.Н. Павлова [22] вказують на те, що підвищення середньорічної температури і зниження річної суми опадів збільшують вміст білку у зерні, а вміст крохмалю при цьому знижується.

Найбільший вміст та вихід крохмалю в середньому за три роки $(75,40 \%$ та 7,54 т/га) відзначено у групі середньостиглих гібридів, вони істотно $\left(\mathrm{HIP}_{05 \text { група стиглості }}=1,99 \%\right.$ та 0,226 т/га) відрізнялися від його вмісту та виходу в групах ранньостиглих гібридів $(72,33 \%$ та 5,88 т/га) та середньоранніх гібридів (74,48\% та 6,76 т/га). Відзначено зростання вмісту крохмалю у більш пізньостиглих фрорм кукурудзи, які здебільшого представлені зубовидним підвидом.

На вихід крохмалю 3 одиниці площі впливали також особливості гібридів. Найвищий вихід крохмалю одержано в гібридів DKC 4082 - 7,58 т/га, DK 315 7,51 т/га, а інші гібриди мали достовірно нижчий вихід крохмалю, який мав такі показники: DКС 2960 - 5,95 т/га, DKC 2971 - 5,81 т/га, DKC 3472 - 7,00 т/га, DKC 3795 $6,51 \mathrm{т} /$ га $\left(\mathrm{HIP}_{05 \text { гібрид }}=0,16 \mathrm{т} /\right.$ га $)$.

Різниця у виході крохмалю у групі середньоранніх і середньостиглих гібридів становила 0,88-1,66 т/га порівняно з ранньостиглою групою, тобто спостерігається тенденція, подібнадо вмісту крохмалю: збільшення тривалості вегетаційного періоду сприяє збільшенню виходу крохмалю з одиниці площі (рис. 2).

На вміст та вихід крохмалю істотно впливали розміри фрракції насіння. Найвищими ці показники були за сівби насінням крупної фрракції. Так, за сівби насінням 


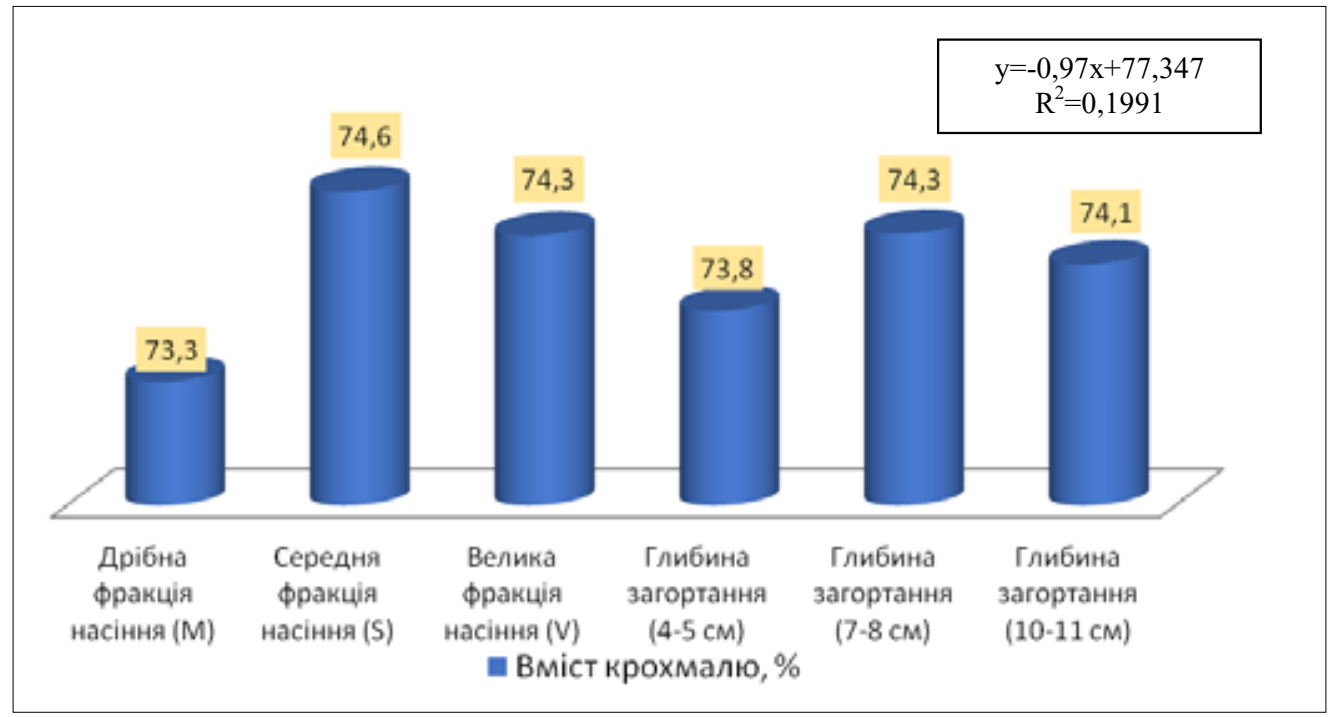

Рис. 1. Вміст крохмалю у зерні кукурудзи залежно від розмірів фрракції та глибини загортання насіння, \% (середнє за 2014-2016 роки)

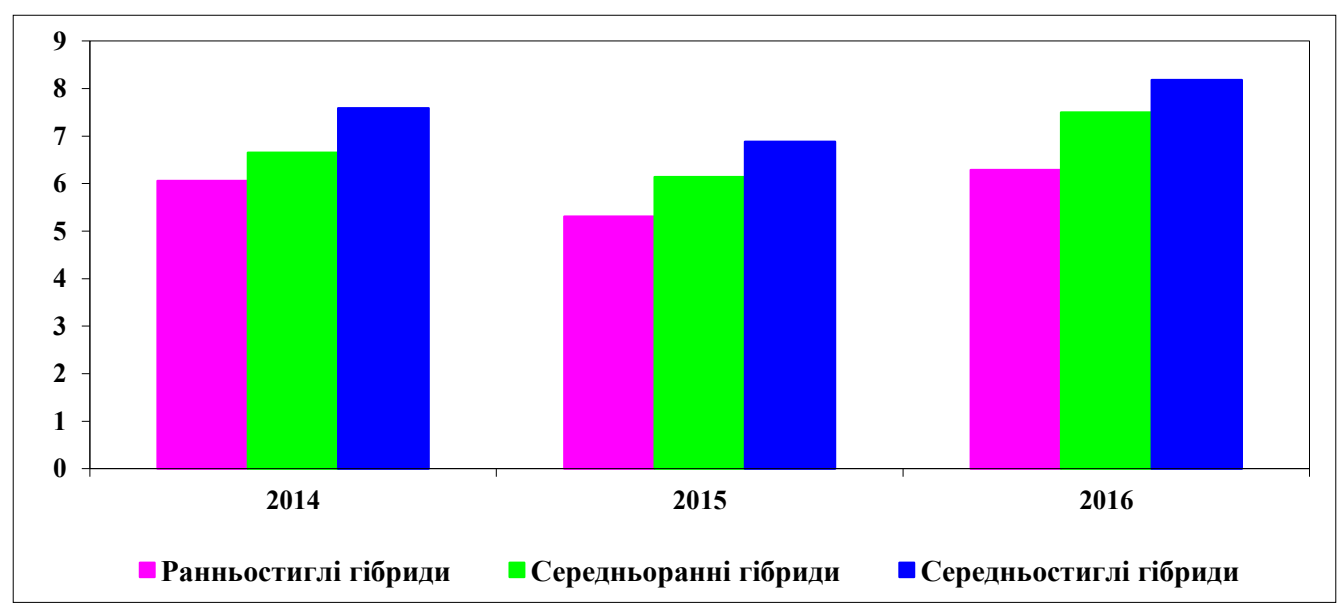

Puc. 2. Вихід крохмалю з одиниці площі залежно від досліджуваних елементів технології вирощування, m/га (середнє за 2014-2016 роки)

Таблиця 4 - Вміст та вихід крохмалю у гібридів кукурудзи залежно від розмірів фракції та глибини загортання насіння (середнє за 2014-2016 роки)

\begin{tabular}{|c|c|c|c|c|c|}
\hline $\begin{array}{c}\text { Група стиглості } \\
\text { (A) }\end{array}$ & $\begin{array}{l}\text { Гібрид } \\
\text { (В) }\end{array}$ & $\begin{array}{c}\text { Фракція насіння } \\
\text { (С) }\end{array}$ & $\begin{array}{c}\text { Глибина } \\
\text { загортання } \\
\text { насіння (D) } \\
\end{array}$ & $\begin{array}{c}\text { Вміст крохмалю } \\
\text { в АСР, \% }\end{array}$ & $\begin{array}{c}\text { Вихід крохмалю, } \\
\text { т/га }\end{array}$ \\
\hline 1 & 2 & 3 & 4 & 5 & 6 \\
\hline \multirow{12}{*}{$\begin{array}{l}\text { Ранньостиглі } \\
\text { гібриди }\end{array}$} & \multirow{9}{*}{ DKC 2960} & \multirow{3}{*}{$M^{*}(187$ г) } & $4-5 \mathrm{~cm}$ & 71,68 & 5,551 \\
\hline & & & $7-8 \mathrm{~cm}$ & 72,00 & 5,563 \\
\hline & & & $10-11 \mathrm{~cm}$ & 71,87 & 5,176 \\
\hline & & \multirow{3}{*}{$\mathrm{S}^{* *}(238$ г) } & $4-5 \mathrm{~cm}$ & 72,71 & 6,190 \\
\hline & & & $7-8 \mathrm{~cm}$ & 73,35 & 6,245 \\
\hline & & & $10-11 \mathrm{~cm}$ & 73,07 & 6,129 \\
\hline & & \multirow{3}{*}{$\mathrm{V}^{* \star *}(277$ г) } & $4-5 \mathrm{~cm}$ & 72,32 & 6,196 \\
\hline & & & $7-8 \mathrm{~cm}$ & 72,87 & 6,175 \\
\hline & & & $10-11 \mathrm{~cm}$ & 73,11 & 6,348 \\
\hline & \multirow{3}{*}{ DKC 2971} & \multirow{3}{*}{$\mathrm{M}^{*}(194$ г) } & $4-5 \mathrm{~cm}$ & 71,64 & 5,570 \\
\hline & & & $7-8 \mathrm{~cm}$ & 71,74 & 5,476 \\
\hline & & & $10-11 \mathrm{~cm}$ & 71,46 & 5,063 \\
\hline
\end{tabular}


Селекція, насінництво

Закінчення таблиці 4

\begin{tabular}{|c|c|c|c|c|c|}
\hline 1 & 2 & 3 & 4 & 5 & 6 \\
\hline \multirow{6}{*}{$\begin{array}{l}\text { Ранньостиглі } \\
\text { гібриди }\end{array}$} & \multirow{6}{*}{ DKC 2971} & \multirow{3}{*}{$\mathrm{S}^{* *}(256$ г) } & $4-5 \mathrm{~cm}$ & 72,47 & 6,014 \\
\hline & & & $7-8 \mathrm{~cm}$ & 72,22 & 5,983 \\
\hline & & & $10-11 \mathrm{~cm}$ & 72,54 & 5,954 \\
\hline & & \multirow{3}{*}{$\mathrm{V}^{* \star *}(279$ г $)$} & $4-5 \mathrm{~cm}$ & 72,12 & 6,105 \\
\hline & & & $7-8 \mathrm{~cm}$ & 72,61 & 6,101 \\
\hline & & & $10-11 \mathrm{~cm}$ & 72,12 & 6,024 \\
\hline \multirow{18}{*}{$\begin{array}{l}\text { Середньоранні } \\
\text { гібриди }\end{array}$} & \multirow{9}{*}{ DKC 3472} & \multirow{3}{*}{$M^{*}(249$ г) } & $4-5 \mathrm{~cm}$ & 73,66 & 6,724 \\
\hline & & & $7-8 \mathrm{~cm}$ & 74,04 & 6,607 \\
\hline & & & $10-11 \mathrm{~cm}$ & 74,26 & 6,420 \\
\hline & & \multirow{3}{*}{$\mathrm{S}^{* *}(326$ г) } & $4-5 \mathrm{~cm}$ & 74,60 & 7,280 \\
\hline & & & $7-8 \mathrm{~cm}$ & 75,13 & 7,255 \\
\hline & & & $10-11 \mathrm{~cm}$ & 74,93 & 7,255 \\
\hline & & \multirow{3}{*}{$V^{* * *}(385$ r) } & $4-5 \mathrm{~cm}$ & 73,71 & 7,151 \\
\hline & & & $7-8 \mathrm{~cm}$ & 74,38 & 7,224 \\
\hline & & & $10-11 \mathrm{~cm}$ & 73,95 & 7,096 \\
\hline & \multirow{9}{*}{ DKC 3795} & \multirow{3}{*}{$M^{*}(166 r)$} & $4-5 \mathrm{~cm}$ & 73,65 & 6,163 \\
\hline & & & $7-8 \mathrm{~cm}$ & 73,94 & 6,074 \\
\hline & & & $10-11 \mathrm{~cm}$ & 73,62 & 5,779 \\
\hline & & \multirow{3}{*}{$S^{* *}(207$ г) } & $4-5 \mathrm{~cm}$ & 74,40 & 6,836 \\
\hline & & & $7-8 \mathrm{~cm}$ & 74,92 & 6,515 \\
\hline & & & $10-11 \mathrm{~cm}$ & 75,36 & 6,637 \\
\hline & & \multirow{3}{*}{$\mathrm{V}^{* \star *}(287$ r) } & $4-5 \mathrm{~cm}$ & 74,85 & 6,946 \\
\hline & & & $7-8 \mathrm{~cm}$ & 75,73 & 6,778 \\
\hline & & & $10-11 \mathrm{~cm}$ & 75,49 & 6,890 \\
\hline \multirow{18}{*}{$\begin{array}{c}\text { Середньостиглі } \\
\text { гібриди }\end{array}$} & \multirow{9}{*}{ DK 315} & \multirow{3}{*}{$M^{*}(223$ г) } & $4-5 \mathrm{~cm}$ & 74,46 & 7,100 \\
\hline & & & $7-8 \mathrm{~cm}$ & 74,72 & 7,072 \\
\hline & & & $10-11 \mathrm{~cm}$ & 74,32 & 6,778 \\
\hline & & \multirow{3}{*}{$\mathrm{S}^{* \star}(294$ г) } & $4-5 \mathrm{~cm}$ & 75,70 & 7,594 \\
\hline & & & $7-8 \mathrm{~cm}$ & 76,16 & 7,776 \\
\hline & & & $10-11 \mathrm{~cm}$ & 75,69 & 7,728 \\
\hline & & \multirow{3}{*}{$V^{* * *}(327$ r) } & $4-5 \mathrm{~cm}$ & 75,53 & 7,787 \\
\hline & & & $7-8 \mathrm{~cm}$ & 75,66 & 7,969 \\
\hline & & & $10-11 \mathrm{~cm}$ & 75,36 & 7,774 \\
\hline & \multirow{9}{*}{ DKC 4082} & \multirow{3}{*}{$\mathrm{M}^{*}(172$ г) } & $4-5 \mathrm{~cm}$ & 73,80 & 7,001 \\
\hline & & & $7-8 \mathrm{~cm}$ & 74,62 & 6,971 \\
\hline & & & $10-11 \mathrm{~cm}$ & 74,36 & 6,732 \\
\hline & & \multirow{3}{*}{$S^{* *}(227$ г) } & $4-5 \mathrm{~cm}$ & 76,13 & 7,657 \\
\hline & & & $7-8 \mathrm{~cm}$ & 76,78 & 8,117 \\
\hline & & & $10-11 \mathrm{~cm}$ & 76,46 & 8,127 \\
\hline & & \multirow{3}{*}{$\mathrm{V}^{* \star *}(278$ г) } & $4-5 \mathrm{~cm}$ & 74,93 & 7,573 \\
\hline & & & $7-8 \mathrm{~cm}$ & 76,64 & 8,048 \\
\hline & & & $10-11 \mathrm{~cm}$ & 75,92 & 7,997 \\
\hline \multicolumn{4}{|l|}{$\mathrm{HIP}_{05 \text { група стиглості }}$} & 2,45 & 0,18 \\
\hline $\mathrm{HIP}_{05 \text { гібрид }}$ & & & & 3,57 & 0,97 \\
\hline $\mathrm{HIP}_{05 \text { фракція насіння }}$ & & & & 2,31 & 0,63 \\
\hline $\mathrm{HIP}_{05}$ глибина загортання & & & & 0,22 & 0,64 \\
\hline
\end{tabular}

* дрібна фрракція насіння; ** середня фрракція насіння; *** велика фрракція насіння

дрібної фрракції вміст крохмалю у зерні становив 73,33\%, а його вихід перебував у межах 5,43-6,98 т/га, що в середньому становило 6,21 т/га, середньої - 74,59\% і 5,98-7,97 т/га та 6,96, великої - 74,3\% і 6,08-7,87 т/га та $7,01 \mathrm{~T} /$ га $\left(\mathrm{HIP}_{05 \text { фракція насіння }}=0,28 \%\right.$ та 0,558 т/га).

Використання мілкої (4-5 см) глибини загортання зерна забезпечило вміст та вихід крохмалю 72,08-75,23\% та 5,9-7,49 т/га, або в серед- ньому 6,75 т/га, середньої (7-8 см) - 72,19-76,02\% і 5,85-7,71 т/га, або в середньому 6,78 т/га, глибокої (10-11 см) - 72,04-75,58\% і 5,68-7,62 т/га, або в середньому 6,66 т/г (HIP 05 глибина загортання $=0,22 \%$ та 0,213 т/га). Відповідно, найвищий вміст крохмалю у зерні в середньому за три роки за глибини загортання 7-8 см склав $74,31 \%$, тоді як за глибини загортання 4-5 см - 73,8\%, а за глибини 10-11 см - 74,11\%. 
Дослідженнями встановлено залежність виходу біоетанолу від груп стиглості гібридів, їх сортових особливостей, елементів технології (строків сівби, позакореневих підживлень та глибини загортання насіння і розмірів його фрракції) (табл. 5).

Вихід біоетанолу у групі ранньостиглих гібридів становив 3,131 тис. л/га, середньоранніх -
3,551 тис. л/га, а середньостиглих - 4,139 тис. л/га $\left(\mathrm{HIP}_{05}\right.$ група стиглості $=0,09$ тис. л/га), тобто використання середньостиглих гібридів кукурудзи забезпечує додатковий вихід цього біопалива 0,588-1,008 тис. л/га порівняно зі скоростиглими формами.

Використання гібридів ранньостиглої групи DKC 2971, DKC 2960, DKC 2787, середньоранньої групи DКC

Таблиця 5 - Вихід біоетанолу з одиниці площі залежно від строку сівби, тис. л/га (за 2011-2013 роки)

\begin{tabular}{|c|c|c|c|c|c|c|}
\hline \multirow{2}{*}{$\begin{array}{c}\text { Група стиглості } \\
\text { (A) }\end{array}$} & \multirow{2}{*}{$\begin{array}{l}\text { Гібрид } \\
\text { (В) }\end{array}$} & \multirow{2}{*}{$\begin{array}{c}\text { Строки сівби } \\
\text { (С) }\end{array}$} & \multicolumn{3}{|c|}{ Роки досліджень } & \multirow{2}{*}{ Середне } \\
\hline & & & 2011 & 2012 & 2013 & \\
\hline 1 & 2 & 3 & 4 & 5 & 6 & 7 \\
\hline \multirow{18}{*}{$\begin{array}{c}\text { Ранньостигла } \\
\text { група }\end{array}$} & \multirow{3}{*}{ Харківський 195МВ } & Ранній $\left(\mathrm{PT}^{*} \mathrm{t}=+8^{\circ} \mathrm{C}\right)$ & 3,763 & 3,092 & 3,386 & 3,414 \\
\hline & & Середній (РТГ t=+10²) & 3,529 & 2,891 & 3,275 & 3,232 \\
\hline & & Пізній $\left(\right.$ РТГ $\left.\mathrm{t}=+12^{\circ} \mathrm{C}\right)$ & 3,003 & 2,390 & 2,741 & 2,711 \\
\hline & \multirow{3}{*}{ DKC 2870} & Ранній $\left(\mathrm{PT}^{*} \mathrm{t}=+8^{\circ} \mathrm{C}\right)$ & 3,780 & 3,242 & 3,507 & 3,510 \\
\hline & & Середній (РТГ $\left.\mathrm{t}=+10^{\circ} \mathrm{C}\right)$ & 3,257 & 2,817 & 3,508 & 3,194 \\
\hline & & Пізній (РТГ t=+12º & 2,966 & 2,439 & 2,566 & 2,657 \\
\hline & \multirow{3}{*}{ DKC 2960} & Ранній $\left(\mathrm{PT}^{*} \mathrm{t}=+8^{\circ} \mathrm{C}\right)$ & 4,290 & 3,012 & 3,439 & 3,580 \\
\hline & & Середній (РТГ $\left.\mathrm{t}=+10^{\circ} \mathrm{C}\right)$ & 3,592 & 2,776 & 3,502 & 3,290 \\
\hline & & Пізній (РТГ $\left.\mathrm{t}=+12^{\circ} \mathrm{C}\right)$ & 3,142 & 2,450 & 3,081 & 2,891 \\
\hline & \multirow{3}{*}{ DKC 2949} & Ранній $\left(\mathrm{PT} \Gamma^{*} \mathrm{t}=+8^{\circ} \mathrm{C}\right)$ & 3,526 & 2,700 & 3,291 & 3,172 \\
\hline & & Середній (РТГ $\left.\mathrm{t}=+10^{\circ} \mathrm{C}\right)$ & 2,932 & 2,451 & 2,835 & 2,739 \\
\hline & & Пізній $\left(\right.$ РТГ $\left.\mathrm{t}=+12^{\circ} \mathrm{C}\right)$ & 2,625 & 1,966 & 2,824 & 2,472 \\
\hline & \multirow{3}{*}{ DKC 2787} & Ранній $\left(\mathrm{PT}^{*} \mathrm{t}=+8^{\circ} \mathrm{C}\right)$ & 3,745 & 3,110 & 3,480 & 3,445 \\
\hline & & Середній (РТГ $\left.\mathrm{t}=+10^{\circ} \mathrm{C}\right)$ & 3,429 & 2,876 & 3,392 & 3,232 \\
\hline & & Пізній $\left(\right.$ РТГ $\left.\mathrm{t}=+12^{\circ} \mathrm{C}\right)$ & 3,217 & 2,352 & 3,236 & 2,935 \\
\hline & \multirow{3}{*}{ DKC 2971 (st) } & Ранній $\left(\mathrm{PT}^{*} \mathrm{t}=+8^{\circ} \mathrm{C}\right)$ & 3,845 & 2,965 & 3,503 & 3,438 \\
\hline & & Середній (РТГ $\left.\mathrm{t}=+10^{\circ} \mathrm{C}\right)$ & 3,784 & 2,959 & 3,468 & 3,404 \\
\hline & & Пізній $\left(\right.$ РТГ $\left.\mathrm{t}=+12^{\circ} \mathrm{C}\right)$ & 3,524 & 2,483 & 3,142 & 3,050 \\
\hline \multirow{18}{*}{$\begin{array}{c}\text { Середньорання } \\
\text { група }\end{array}$} & \multirow{3}{*}{ DKC 3476} & Ранній $\left(\mathrm{PT}^{*} \mathrm{t}=+8^{\circ} \mathrm{C}\right)$ & 4,128 & 3,387 & 4,025 & 3,847 \\
\hline & & Середній (РТГ $\left.\mathrm{t}=+10^{\circ} \mathrm{C}\right)$ & 4,213 & 3,005 & 3,912 & 3,710 \\
\hline & & Пізній (РТГ t=+12을 & 3,346 & 2,491 & 3,632 & 3,156 \\
\hline & \multirow{3}{*}{ DКС 3795} & Ранній $\left(\mathrm{PT}^{*} \mathrm{t}=+8^{\circ} \mathrm{C}\right)$ & 4,486 & 3,335 & 4,315 & 4,045 \\
\hline & & Середній (РТГ $\left.\mathrm{t}=+10^{\circ} \mathrm{C}\right)$ & 3,661 & 3,007 & 3,850 & 3,506 \\
\hline & & Пізній $\left(\right.$ РТГ $\left.\mathrm{t}=+12^{\circ} \mathrm{C}\right)$ & 3,339 & 2,150 & 3,203 & 2,897 \\
\hline & \multirow{3}{*}{ DKC 3472} & Ранній $\left(\mathrm{PT}^{*} \mathrm{t}=+8^{\circ} \mathrm{C}\right)$ & 4,505 & 3,616 & 4,440 & 4,187 \\
\hline & & Середній (РТГ $\left.\mathrm{t}=+10^{\circ} \mathrm{C}\right)$ & 4,147 & 3,507 & 3,968 & 3,874 \\
\hline & & Пізній $\left(\right.$ РТГ $\left.\mathrm{t}=+12^{\circ} \mathrm{C}\right)$ & 3,630 & 2,850 & 3,642 & 3,374 \\
\hline & \multirow{3}{*}{ DKC 3420} & Ранній $\left(\mathrm{PT}^{*} \mathrm{t}=+8^{\circ} \mathrm{C}\right)$ & 4,518 & 3,363 & 4,362 & 4,081 \\
\hline & & Середній (РТГ $\left.\mathrm{t}=+10^{\circ} \mathrm{C}\right)$ & 3,736 & 3,024 & 3,696 & 3,485 \\
\hline & & Пізній $\left(\right.$ РТГ $\left.\mathrm{t}=+12^{\circ} \mathrm{C}\right)$ & 3,397 & 2,457 & 3,646 & 3,167 \\
\hline & \multirow{3}{*}{ Переяславський 230СВ } & Ранній $\left(\mathrm{PT}^{*} \mathrm{t}=+8^{\circ} \mathrm{C}\right)$ & 4,353 & 3,326 & 3,661 & 3,780 \\
\hline & & Середній (РТГ $\left.\mathrm{t}=+10^{\circ} \mathrm{C}\right)$ & 3,560 & 3,297 & 3,410 & 3,422 \\
\hline & & Пізній $\left(\right.$ РТГ $\left.\mathrm{t}=+12^{\circ} \mathrm{C}\right)$ & 3,281 & 2,243 & 3,354 & 2,959 \\
\hline & \multirow{3}{*}{ DKC 3871 (st) } & Ранній $\left(\mathrm{PT}^{*} \mathrm{t}=+8^{\circ} \mathrm{C}\right)$ & 4,124 & 3,326 & 4,004 & 3,818 \\
\hline & & Середній (РТГ $\left.\mathrm{t}=+10^{\circ} \mathrm{C}\right)$ & 3,736 & 3,017 & 3,697 & 3,483 \\
\hline & & Пізній $\left(\right.$ РТГ $\left.\mathrm{t}=+12^{\circ} \mathrm{C}\right)$ & 3,185 & 2,604 & 3,593 & 3,127 \\
\hline \multirow{9}{*}{$\begin{array}{c}\text { Середньостигла } \\
\text { група }\end{array}$} & \multirow{3}{*}{ DK 391} & Ранній $\left(\mathrm{PT}^{*} \mathrm{t}=+8^{\circ} \mathrm{C}\right)$ & 4,863 & 4,067 & 4,372 & 4,434 \\
\hline & & Середній (РТГ $\left.\mathrm{t}=+10^{\circ} \mathrm{C}\right)$ & 4,150 & 3,373 & 3,946 & 3,823 \\
\hline & & Пізній $\left(\right.$ РТГ $\left.\mathrm{t}=+12^{\circ} \mathrm{C}\right)$ & 3,903 & 3,072 & 3,799 & 3,591 \\
\hline & \multirow{3}{*}{ DKC 3511} & Ранній $\left(\mathrm{PT}^{*} \mathrm{t}=+8^{\circ} \mathrm{C}\right)$ & 4,400 & 3,783 & 4,560 & 4,248 \\
\hline & & Середній (РТГ $\left.\mathrm{t}=+10^{\circ} \mathrm{C}\right)$ & 4,080 & 3,924 & 4,186 & 4,063 \\
\hline & & Пізній $\left(\right.$ РТГ $\left.\mathrm{t}=+12^{\circ} \mathrm{C}\right)$ & 3,749 & 2,933 & 3,953 & 3,545 \\
\hline & & Ранній $\left(\mathrm{PT}^{*} \mathrm{t}=+8^{\circ} \mathrm{C}\right)$ & 4,552 & 4,501 & 4,392 & 4,482 \\
\hline & DK 440 & Середній (РТГ $\left.\mathrm{t}=+10^{\circ} \mathrm{C}\right)$ & 3,965 & 4,105 & 4,275 & 4,115 \\
\hline & & Пізній (РТГ t=+12º & 3,740 & 3,695 & 3,992 & 3,809 \\
\hline
\end{tabular}


Селекція, насінництво

Закінчення таблиці 5

\begin{tabular}{|c|c|c|c|c|c|c|}
\hline 1 & 2 & 3 & 4 & 5 & 6 & 7 \\
\hline \multirow{9}{*}{$\begin{array}{c}\text { Середньостигла } \\
\text { група }\end{array}$} & \multirow{3}{*}{ DKC 4964} & Ранній $\left(\mathrm{PT}^{*} \mathrm{t}=+8^{\circ} \mathrm{C}\right)$ & 4,792 & 4,688 & 4,848 & 4,776 \\
\hline & & Середній (РТГ $\left.\mathrm{t}=+10^{\circ} \mathrm{C}\right)$ & 4,811 & 4,182 & 4,444 & 4,479 \\
\hline & & Пізній $\left(\right.$ РТГ $\left.\mathrm{t}=+12^{\circ} \mathrm{C}\right)$ & 4,267 & 3,667 & 3,896 & 3,943 \\
\hline & \multirow{3}{*}{ DKC 4626} & Ранній $\left(\mathrm{PT}^{*} \mathrm{t}=+8^{\circ} \mathrm{C}\right)$ & 4,560 & 4,458 & 4,918 & 4,645 \\
\hline & & Середній (РТГ $\left.\mathrm{t}=+10^{\circ} \mathrm{C}\right)$ & 4,186 & 4,085 & 4,109 & 4,127 \\
\hline & & Пізній $\left(\right.$ РТГ $\left.\mathrm{t}=+12^{\circ} \mathrm{C}\right)$ & 3,814 & 3,640 & 3,953 & 3,802 \\
\hline & \multirow{3}{*}{ DK 315 (st) } & Ранній $\left(\mathrm{PT}^{*} \mathrm{t}=+8^{\circ} \mathrm{C}\right)$ & 5,454 & 3,771 & 5,088 & 4,771 \\
\hline & & Середній (РТГ $\left.\mathrm{t}=+10^{\circ} \mathrm{C}\right)$ & 4,276 & 3,462 & 4,515 & 4,084 \\
\hline & & Пізній $\left(\right.$ РТГ $\left.\mathrm{t}=+12^{\circ} \mathrm{C}\right)$ & 3,961 & 3,155 & 4,202 & 3,773 \\
\hline \multicolumn{3}{|l|}{$\mathrm{HIP}_{05 \text { група стиглості }}$} & 0,07 & 0,03 & 0,05 & - \\
\hline \multicolumn{3}{|l|}{ HIP ${ }_{05 \text { гібрид }}$} & 0,14 & 0,07 & 0,11 & - \\
\hline \multicolumn{3}{|l|}{$\mathrm{HIP}_{05 \text { строки сівби, }}$} & 0,07 & 0,05 & 0,06 & - \\
\hline
\end{tabular}

* РТГ - рівень температурного режиму ґрунту на глибині загортання насіння

3472, DKC 3420, DKC 3476 та середньостиглої групи DKC 4964, DK 315, DKC 4626, DK 440 дасть змогу істотно збільшити вихід біоетанолу з одиниці площі.

Запізнення зі строками сівби гібридів кукурудзи приводить до зменшення виходу біоетанолу (HIP 05 строки сівби $=0,09$ тис. л/га) на 0,640-0,847 тис. л/га порівняно з раннім строком сівби.

Вихід біоетанолу у групі ранньостиглих гібридів складав 3,903 тис. л/га, середньоранніх - 4,495 тис. л/га, середньостиглих - 5,097 тис. л/га $\left(\mathrm{HIP}_{05 \text { група стиглості }}=0,11\right.$ тис. л/га). Використання гібридів кукурудзи з тривалим вегетаційним періодом забезпечує підвищення виходу біоетанолу на 0,602-1,194 тис. л/га порівняно зі скоростиглими формами.

Використання таких гібридів, як DKC 2960, DKC 3472 та DKC 3420, DKC 4964 і DK 315, дасть змогу збільшити вихід біоетанолу на 0,462-0,629 тис. л/га $\left(\mathrm{HIP}_{05 \text { гібрид }}=0,93\right.$ тис. л/га). Позакореневі підживлення забезпечили зростання виходу біоетанолу, яке в серед- ньому за три роки досліджень становило 0,1-1,04 тис. л/га $\left(\mathrm{HIP}_{05}\right.$ підживлення $=0,35 \mathrm{Tиc}$. л/га) відносно контролю (підживлення водою).

Зростання виходу біоетанолу за одноразового позакореневого підживлення становило 0,10-0,65 тис. л/га, а за дворазового позакореневого підживлення - 0,30-1,04 тис. л/га порівняно з контролем (підживлення водою) $\left(\mathrm{HIP}_{05}\right.$ кількість підживлень $=0,36$ тис. л/га).

У групі ранньостиглих гібридів орієнтовний вихід біоетанолу (HIP 05 група стиглості $=0,124$ тис. л/га), в середньому за три роки склав 3,22 тис. л/га, середньоранніх 3,70 тис. л/га, середньостиглих - 4,13 тис. л/га (табл. 6).

За роками досліджень орієнтовний вихід біоетанолу змінювався залежно від умов року. У середньому в досліджуваних гібридів за 2014 рік він склав 3,70 тис. л/га, за 2015 рік - 3,34 тис. л/га, у 2016 році - 4,01 тис. л/га. Найбільш сприятливим роком для цього показника за вологозабезпеченням та температурними показниками був 2016 рік.

Таблиця 6 - Орієнтовний вихід біоетанолу з одиниці площі посіву гібридів кукурудзи залежно від умов вегетації та факторів технології вирощування, тис. л/га (за 2014-2016 роки)

\begin{tabular}{|c|c|c|c|c|c|c|c|}
\hline \multirow{2}{*}{$\begin{array}{c}\text { Група стиглості } \\
\text { (A) }\end{array}$} & \multirow{2}{*}{$\begin{array}{c}\text { Гібрид } \\
\text { (В) }\end{array}$} & \multirow{2}{*}{$\begin{array}{l}\text { Фракція насіння } \\
\text { (C) }\end{array}$} & \multirow{2}{*}{$\begin{array}{c}\text { Глибина } \\
\text { загортання } \\
\text { насіння (D) }\end{array}$} & \multicolumn{3}{|c|}{ Рік } & \multirow{2}{*}{ Середнє } \\
\hline & & & & 2014 & 2015 & 2016 & \\
\hline 1 & 2 & 3 & 4 & 5 & 6 & 7 & 8 \\
\hline \multirow{15}{*}{$\begin{array}{c}\text { Ранньостиглі } \\
\text { гібриди }\end{array}$} & \multirow{9}{*}{ DKC 2960} & \multirow{3}{*}{$M^{*}(187$ г) } & $4-5 \mathrm{~cm}$ & 3,001 & 2,748 & 3,375 & 3,041 \\
\hline & & & $7-8 \mathrm{~cm}$ & 3,162 & 2,804 & 3,178 & 3,048 \\
\hline & & & $10-11 \mathrm{~cm}$ & 2,930 & 2,678 & 2,901 & 2,836 \\
\hline & & \multirow{3}{*}{$\mathrm{S}^{* *}(238$ г) } & $4-5 \mathrm{~cm}$ & 3,763 & 2,811 & 3,600 & 3,391 \\
\hline & & & $7-8 \mathrm{~cm}$ & 3,760 & 2,991 & 3,513 & 3,421 \\
\hline & & & $10-11 \mathrm{~cm}$ & 3,627 & 2,968 & 3,479 & 3,358 \\
\hline & & \multirow{3}{*}{$\mathrm{V}^{* * *}(277$ г) } & $4-5 \mathrm{~cm}$ & 3,659 & 2,803 & 3,722 & 3,395 \\
\hline & & & $7-8 \mathrm{~cm}$ & 3,595 & 2,927 & 3,628 & 3,383 \\
\hline & & & $10-11 \mathrm{~cm}$ & 3,637 & 3,041 & 3,756 & 3,478 \\
\hline & \multirow{6}{*}{ DKC 2971} & \multirow{3}{*}{$M^{*}(194$ г) } & $4-5 \mathrm{~cm}$ & 2,938 & 2,805 & 3,413 & 3,052 \\
\hline & & & $7-8 \mathrm{~cm}$ & 2,832 & 2,791 & 3,377 & 3,000 \\
\hline & & & $10-11 \mathrm{~cm}$ & 2,746 & 2,658 & 2,918 & 2,774 \\
\hline & & \multirow{3}{*}{$S^{* *}(256 r)$} & $4-5 \mathrm{~cm}$ & 3,254 & 3,170 & 3,461 & 3,295 \\
\hline & & & $7-8 \mathrm{~cm}$ & 3,227 & 3,047 & 3,560 & 3,278 \\
\hline & & & $10-11 \mathrm{~cm}$ & 3,341 & 2,966 & 3,481 & 3,263 \\
\hline \multirow{3}{*}{$\begin{array}{c}\text { Ранньостиглі } \\
\text { гібриди }\end{array}$} & \multirow{3}{*}{ DKC 2971} & \multirow{3}{*}{$\mathrm{V}^{* \star \star}(279$ г) } & $4-5 \mathrm{~cm}$ & 3,400 & 3,112 & 3,524 & 3,345 \\
\hline & & & $7-8 \mathrm{~cm}$ & 3,364 & 3,030 & 3,635 & 3,343 \\
\hline & & & $10-11 \mathrm{~cm}$ & 3,449 & 2,981 & 3,471 & 3,300 \\
\hline
\end{tabular}


Селекція, насінництво

\begin{tabular}{|c|c|c|c|c|c|c|c|}
\hline & & & & & & Закінче & таблиь \\
\hline \multirow{18}{*}{$\begin{array}{l}\text { Середньоранні } \\
\text { гібриди }\end{array}$} & \multirow{9}{*}{ DKC 3472} & \multirow{3}{*}{$\mathrm{M}^{*}(249$ г) } & $4-5 \mathrm{~cm}$ & 3,374 & 3,181 & 4,497 & 3,684 \\
\hline & & & $7-8 \mathrm{~cm}$ & 3,445 & 3,140 & 4,275 & 3,620 \\
\hline & & & $10-11 \mathrm{~cm}$ & 3,345 & 3,109 & 4,098 & 3,517 \\
\hline & & \multirow{3}{*}{$S^{* *}(326$ г) } & $4-5 \mathrm{~cm}$ & 3,776 & 3,634 & 4,556 & 3,989 \\
\hline & & & $7-8 \mathrm{~cm}$ & 3,779 & 3,527 & 4,619 & 3,975 \\
\hline & & & $10-11 \mathrm{~cm}$ & 3,846 & 3,536 & 4,543 & 3,975 \\
\hline & & \multirow{3}{*}{$\mathrm{V}^{* * *}(385 r)$} & $4-5 \mathrm{~cm}$ & 3,722 & 3,488 & 4,544 & 3,918 \\
\hline & & & $7-8 \mathrm{~cm}$ & 3,812 & 3,587 & 4,475 & 3,958 \\
\hline & & & $10-11 \mathrm{~cm}$ & 3,829 & 3,373 & 4,462 & 3,888 \\
\hline & \multirow{9}{*}{ DKC 3795} & \multirow{3}{*}{$M^{*}(166$ г) } & $4-5 \mathrm{~cm}$ & 3,388 & 3,121 & 3,621 & 3,377 \\
\hline & & & $7-8 \mathrm{~cm}$ & 3,258 & 3,169 & 3,558 & 3,328 \\
\hline & & & $10-11 \mathrm{~cm}$ & 3,230 & 2,988 & 3,280 & 3,166 \\
\hline & & \multirow{3}{*}{$S^{* *}(207$ г) } & $4-5 \mathrm{~cm}$ & 3,679 & 3,627 & 3,930 & 3,745 \\
\hline & & & $7-8 \mathrm{~cm}$ & 3,723 & 3,308 & 3,678 & 3,570 \\
\hline & & & $10-11 \mathrm{~cm}$ & 3,808 & 3,364 & 3,736 & 3,636 \\
\hline & & \multirow{3}{*}{$\mathrm{V}^{* \star *}(287$ г) } & $4-5 \mathrm{~cm}$ & 3,782 & 3,688 & 3,948 & 3,806 \\
\hline & & & $7-8 \mathrm{~cm}$ & 3,879 & 3,236 & 4,025 & 3,713 \\
\hline & & & $10-11 \mathrm{~cm}$ & 3,865 & 3,410 & 4,050 & 3,775 \\
\hline \multirow{18}{*}{$\begin{array}{c}\text { Середньостиглі } \\
\text { гібриди }\end{array}$} & \multirow{9}{*}{ DK 315} & \multirow{3}{*}{$M^{*}(223$ г) } & $4-5 \mathrm{~cm}$ & 3,816 & 3,509 & 4,345 & 3,890 \\
\hline & & & $7-8 \mathrm{~cm}$ & 3,901 & 3,477 & 4,247 & 3,875 \\
\hline & & & $10-11 \mathrm{~cm}$ & 3,863 & 3,230 & 4,048 & 3,714 \\
\hline & & \multirow{3}{*}{$S^{* *}(294$ г) } & $4-5 \mathrm{~cm}$ & 4,184 & 3,845 & 4,452 & 4,160 \\
\hline & & & $7-8 \mathrm{~cm}$ & 4,366 & 3,841 & 4,574 & 4,260 \\
\hline & & & $10-11 \mathrm{~cm}$ & 4,446 & 3,758 & 4,498 & 4,234 \\
\hline & & \multirow{3}{*}{$\mathrm{V}^{* * *}(327$ г) } & $4-5 \mathrm{~cm}$ & 4,195 & 4,011 & 4,594 & 4,267 \\
\hline & & & $7-8 \mathrm{~cm}$ & 4,496 & 3,932 & 4,671 & 4,366 \\
\hline & & & $10-11 \mathrm{~cm}$ & 4,289 & 3,854 & 4,636 & 4,260 \\
\hline & \multirow{9}{*}{ DKC 4082} & \multirow{3}{*}{$\mathrm{M}^{*}(172$ г) } & $4-5 \mathrm{~cm}$ & 3,724 & 3,701 & 4,083 & 3,836 \\
\hline & & & $7-8 \mathrm{~cm}$ & 3,779 & 3,617 & 4,062 & 3,819 \\
\hline & & & $10-11 \mathrm{~cm}$ & 3,685 & 3,406 & 3,974 & 3,688 \\
\hline & & \multirow{3}{*}{$S^{* *}(227$ г) } & $4-5 \mathrm{~cm}$ & 3,971 & 3,923 & 4,691 & 4,195 \\
\hline & & & $7-8 \mathrm{~cm}$ & 4,441 & 3,996 & 4,905 & 4,447 \\
\hline & & & $10-11 \mathrm{~cm}$ & 4,625 & 3,890 & 4,843 & 4,453 \\
\hline & & \multirow{3}{*}{$\mathrm{V}^{* * \star}(278$ г) } & $4-5 \mathrm{~cm}$ & 4,088 & 3,903 & 4,457 & 4,149 \\
\hline & & & $7-8 \mathrm{~cm}$ & 4,437 & 3,976 & 4,816 & 4,410 \\
\hline & & & $10-11 \mathrm{~cm}$ & 4,488 & 3,904 & 4,753 & 4,382 \\
\hline \multicolumn{4}{|l|}{$\mathrm{HIP}_{05 \text { група стиглості }}$} & 0,08 & 0,03 & 0,03 & - \\
\hline \multicolumn{4}{|l|}{$\mathrm{HIP}_{05 \text { гібрид }}$} & 0,03 & 0,03 & 0,04 & - \\
\hline \multicolumn{4}{|l|}{ HIP $_{05 \text { фракція насіння }}$} & 0,05 & 0,04 & 0,04 & - \\
\hline \multicolumn{4}{|l|}{$\mathrm{HIP}_{05 \text { глибина загортання }}$} & 0,05 & 0,05 & 0,06 & - \\
\hline
\end{tabular}

* дрібна фрракція насіння; ** середня фракція насіння; ${ }^{* * *}$ велика фрракція насіння

На орієнтовний вихід біоетанолу впливала фракція насіння $\left(\mathrm{HIP}_{05}\right.$ фракція насіння $=0,306$ тис. л/га). Зокрема, вихід біоетанолу за сівби насінням дрібної фракції в середньому за три роки досліджень коливався в межах 2,94-3,78 тис. л/га, або в середньому для фракції 3,41 тис. л/га, за сівби насінням середньої фракції 3,28-4,36 тис. л/га або в середньому для фракції 3,81, а за сівби насінням великої фракції - 3,33-4,31 тис. л/га або в середньому для фракції 3,84 тис. л/га (рис. 3).

Глибина загортання насіння кукурудзи неоднозначно $\left(\mathrm{HIP}_{05}\right.$ глибина загортання насіння $=0,117$ тис. л/га) впливала на вихід біоетанолу із зерна.

Так, використання неглибокого (4-5 см) загортання насіння сприяло виходу біоетанолу в середньому за три роки в межах 3,23-4,11 тис. л/га або в середньому для цієї глибини 3,697 тис. л/га, за використання середньої (7-8 см) глибини загортання - 3,21-4,23 тис. л/га або в середньому - 3,713 тис. л/га, а за використання глибокого (10-11 см) загортання - 3,11-4,17 тис. л/га або в середньому - 3,648 тис. л/га, тобто збільшення глибини загортання насіння приводить до зменшення виходу біоетанолу з одиниці посіву.

Висновки. Вміст та вихід крохмалю з одиниці площі істотно залежали від групи стиглості гібридів. Використання гібридів кукурудзи з тривалим вегетаційним періодом зубовидного підвиду забезпечило підвищення виходу біоетанолу на 0,602-1,194 тис. л/га та вмісту крохмалю в зерні на 1,53-2,56\% порівняно зі скоростиглими формами. Ранньостиглі гібриди переважно кременисто-зубовидного та кременистого 


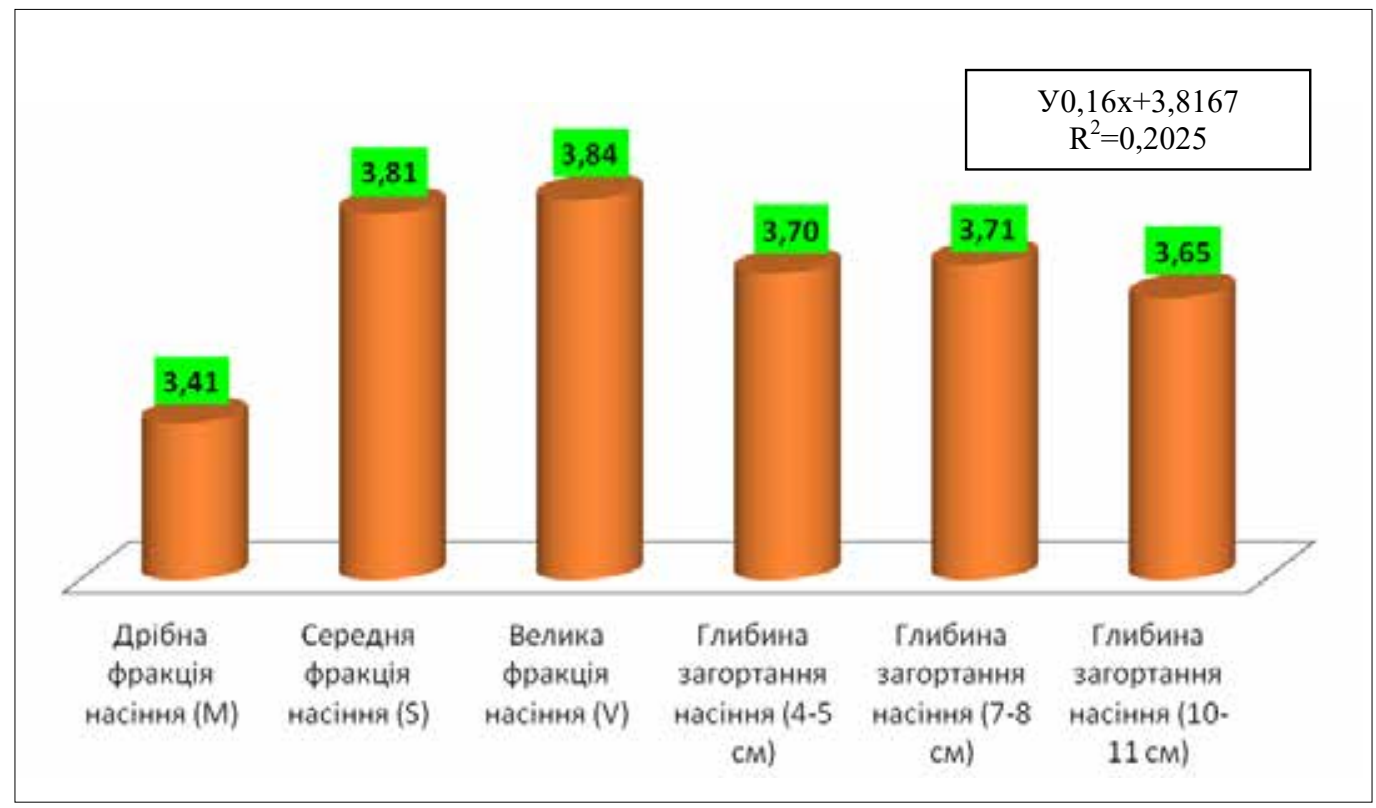

Рис. 3. Орієнтовний вихід біоетанолу з одиниці площі посіву гібридів кукурудзи залежно від умов вегетації та факторів технології вирощування, тис. л/га (середнє за 2014-2016 роки)

підвидів мають високу ранньостиглість та холодостійкість, але низький вміст крохмалю (71,56-73,33\%), тоді як зубовидні гібриди мають подовжений вегетаційний період, високу врожайність зерна та підвищений вміст крохмалю $(73,13-75,06 \%)$.

Відзначено зростання вмісту, виходу крохмалю та біоетанолу з одиниці площі у гібридів DКC 2870 , Харківський 195MB та DKC 2971 ранньостиглої групи, DKC 3420, DKC 3476 та DKC 3795 середньоранньої групи, DKC 4964, DKC 3511 та DK 440 середньостиглої групи. Використання цих гібридів дасть змогу збільшити вихід біоетанолу на 0,462-0,629 тис. л/га.

Застосування пізніх строків сівби сприяє зростанню вмісту крохмалю на 1,57-1,97\% та приводить до зменшення виходу біоетанолу на 0,640-0,847 тис. л/га порівняно з раннім строком сівби за рахунок скорочення рівня урожайності під час запізнення сівби. Встановлено, що в посушливі з високими температурами роки (2012 та 2015 роки) відбувається зниження вмісту крохмалю $(72,06-74,39 \%$ та 69,43-74,56\%) незалежно від досліджуваних фракторів вегетації та технології вирощування.

Позакореневі підживлення сприяли збільшенню вмісту крохмалю у зерні (на 0,1-0,46\% у 2011-2013 роки) та виходу біоетанолу на 0,1-1,04 тис. л/га порівняно з контролем (без позакореневих підживлень). Зростання виходу біоетанолу за одноразового позакореневого підживлення становило 0,10-0,65 тис. л/га, а за дворазового підживлення - 0,30-1,04 тис. л/га відносно контролю.

За сівби насінням середньої та великої фракції одержано найвищий вміст крохмалю, а саме 74,59\% та $74,30 \%$, порівняно з використанням дрібної фрракції насіння (73,33\%). Зростання вмісту крохмалю за використання середньої фракції насіння становило 0,8-2,2\%, великої - 0,02-1,67\% відносно дрібної. Загортання насіння на глибину 7-8 см забезпечує найвищий вміст крохмалю $74,31 \%$, тоді як загортання на глибину 4-5 см - 73,80\%, а на глибину $10-11$ см $-74,11 \%$.

\section{СПИСОК ВИКОРИСТАНОÏ ЛІТЕРАТУРИ:}

1. Соколік С.П. Перспективи використання кукурудзи на зерно в якості біопалива. Вісник Харківського національного технічного університету сільського господарства імені Петра Василенка. 2016. Вип. 173. С. 168-176.

2. ПаламарчукВ.Д., Дідур І.М., КолісникО.М., Алексєєв О.О. Аспекти сучасної технології вирощування висококрохмальної кукурудзи в умовах Лісостепу правобережного. Вінниця : Друк, 2020. 536 с.

3. Мазур В.А., Паламарчук В.Д., Поліщук І.С., Паламарчук О.Д. Новітні агротехнології у рослинництві : підручник. Вінниця, 2017. 588 с.

4. Надь Я. Кукуруза. Вінниця : ФОП Д.Ю. Корзун, 2012. $580 \mathrm{c.}$

5. Аналітика українського ринку експорту кукурудзи. 2015. Інтернет-клуб «Мій бізнес». URL: http://tradehub.com.ua/ru/5546obzory/view/5383/ analitika kukuruza.htm.

6. Полішкевич О.Р. Ефективність використання кукурудзи для виробництва альтернативних палив. Вісник аграрної науки Причорномор'я. 2011. Вип. 3 (60). С. 76-80.

7. Дудка Т.В. Доцільність отримання біоетанолу із зерна кукурудзи. Сортовивчення та охорона прав на сорти рослин. 2012. № 1. С. 44-47.

8. Facts on health and the environment. Biofuel yields for different feedstocks. URL: http://www.greenfacts.org/ en/biofuels/figtableboxes/biofuel-yields-countries.htm.

9. Перспективи розвитку ринку біоетанолу в Україні. URL: http://saee.gov.ua/sites/default/files/ Schulmeister_bioethanol_1.pdf. 
10. Желєзна Т.А., Драгнєв С.В., Баштовий А.І., Роговський І.Л. Перспективи виробництва і споживання біопалив другого покоління в Україні. Machinery \& Energetics. 2018. Vol. 9. № 2. P. 61-66.

11. Каменщук Б.Д. Оцінка гібридів кукурудзи на придатність до виробництва біоетанолу. Агроном. 2013. № 3. C. 162-163.

12. Паламарчук В.Д., Поліщук І.С., Каленська С.М., Єрмакова Л.М. Біологія та екологія сільськогосподарських рослин : підручник. Київ, 2013. 636 с.

13. Рибалка О.І., Червоніс М.В., Моргун Б.В., Починок В.М., Поліщук С.С. Генетичні та селекційні критерії створення сортів зернових культур спирто-дистилятного напряму технологічного використання зерна. Физиология и биохимия культурных растений. 2013. T. 45. № 1. С. 3-20.

14. В Україні зареєстровано гібрид кукурудзи для виробництва біоетанолу. URL: https://superagronom.com/ news/4996-v-ukrayini-zareyestrovano-gibrid-kukurudzidlya-virobnitstva-bioetanolu.

15. Лебідь Є.М., Циков В.С., Пащенко Ю.М. та ін. Методика проведення польових дослідів з кукурудзою. Дніпропетровськ, 2008. 27 с.

16. Столяренко В.С., Остапенко Л.І., Пончик Л.І. Допосівна, післязбиральна підготовка та посівні властивості різноякісного насіння кукурудзи. Бюлетень інституту зернового господарства УААН. 2003. № 20. C. $59-60$.

17. ГОСТ 46.045:2003 «Зерно. Методи визначення умовної крохмалистості» від 25 липня 2003 року № 250.

18. Wu X., Zhao R., Wang D., Bean S., Seib P.A., Tuinstra M.R., Campbell M., O'Brien A. Effects of amylose amylopectin ratio, corn protein and corn fiber contents on ethanol production. Cereal Chemistry. 2006. № 83 , 5. P. $569-575$.

19. Блюм Я.Б., Гелетуха Г.Г., Григорюк І.П., Дубровін В.О., Ємець А.І., Забарний Г.М., Калетнік Г.М., Мельничук М.Д., Мироненко В.Г., Рахметов Д.Б., Циганков С.П. Новітні технології біоенергоконверсії : монографія. Київ : Аграр Медіа Груп, 2010. 326 с.

20. AACC International 2000 (AACCI Method 76-13.01 Total Starch Assay Procedure (Megazyme Amyloglucosidase/ alpha-Amylase Method).

21. Пащенко Ю.М., Кордін О.І. Вплив строків сівби на урожайність та показники якості зерна кукурудзи різних груп стиглості. Хранение и переработка зерна. 2010. № 6 (132). Июнь. С. 47-48.

22. Павлов А.Н. Накопление белка в зерне пшеницы и кукурузы. Москва : Наука, 1967. 340 с.

\section{REFERENCES:}

1. Sokolik, S.P. (2016). Perspektyvy vykorystannia kukurudzy na zerno $v$ yakosti biopalyva [Prospects for the use of corn for grain as a biofuel]. Visnyk Kharkivskoho natsionalnoho tekhnichnoho universytetu silskoho hospodarstva imeni Petra Vasylenka - Bulletin of the Petro Vasylenko Kharkiv National Technical University of Agriculture, 173, 168-176 [in Ukrainian].

2. Palamarchuk, V.D., Didur, I.M., Kolisnyk, O.M. \& Alieksieiev, O.O. (2020). Aspekty suchasnoi tekhnolohii vyroshchuvannia vysokokrokhmalnoi kukurudzy $v$ umovakh Lisostepu pravoberezhnoho [Aspects of modern technology of growing high-starch corn in the right-bank forest-steppe]. Vinnytsya: Druk [in Ukrainian].
3. Mazur, V.A., Palamarchuk, V.D., Polishchuk, I.S. \& Palamarchuk, O.D. (2017). Novitni ahrotekhnolohii u roslynnytstvi [The latest agricultural technologies in crop production]. Vinnytsya [in Ukrainian].

4. Nad, Yanosh (2012). Kukuruza [Corn]. Vinnytsya [in Ukrainian].

5. Analityka ukrainskoho rynku eksportu kukurudzy 2015. Internet klub "Mii biznes" [Analysis of the Ukrainian corn export market. 2015. Internet club "My business"]. URL: http://tradehub.com.ua/ru/5546obzory/view/5383/analitika kukuruza.htm.

6. Polishkevych, O.R. (2011). Efektyvnist vykorystannia kukurudzy dlia vyrobnytstva alternatyvnykh palyv [Efficiency of using corn for the production of alternative fuels]. Visnyk ahrarnoi nauky Prychornomoria - Bulletin of Agrarian Science of the Black Sea Region, 3 (60), 76-80 [in Ukrainian].

7. Dudka, T.V. (2012). Dotsilnist otrymannia bioetanolu iz zerna kukurudzy [Expediency of obtaining bioethanol from corn grain]. Sortovyvchennia ta okhorona prav na sorty roslyn - Variety research and protection of plant variety rights, 1, 44-47 [in Ukrainian].

8. Facts on health and the environment. Biofuel yields for different feedstocks. URL: http://www.greenfacts.org/ en/biofuels/figtableboxes/biofuel-yields-countries.htm [in English].

9. Perspektyvy rozvytku rynku bioetanolu $v$ Ukrayini [Prospects for the development of the bioethanol market in Ukraine]. URL: http://saee.gov.ua/sites/default/ files/Schulmeister_bioethanol_1.pdf [in Ukrainian].

10. Zheliezna, T.A., Drahniev, S.V., Bashtovyi, A.I. \& Rohovskyi, I.L. (2018). Perspektyvy vyrobnytstva i spozhyvannia biopalyv druhoho pokolinnia v Ukraini [Prospects for the production and consumption of second-generation biofuels in Ukraine]. Machinery \& Energetics, 9, 2, 61-66 [in Ukrainian].

11. Kamenshchuk, B.D. (2013). Otsinka hibrydiv kukurudzy na prydatnist do vyrobnytstva bioetanolu [Evaluation of maize hybrids for suitability for bioethanol production]. Ahronom - Agronomist, 3, 162-163 in Ukrainian].

12. Palamarchuk, V.D. Polishchuk, I.S., Kalenska, S.M. \& Yermakova, L.M. (2013). Biolohiia ta ekolohiia silskohospodarskykh roslyn [Biology and ecology of agricultural plants]. [in Ukrainian].

13. Rybalka, O.I., Chervonis, M.V., Morhun, B.V., Pochynok, V.M. \& Polishchuk, S.S. (2013). Henetychni ta selektsiini kryterii stvorennia sortiv zernovykh kultur spyrto-dystyliatnoho napriamu tekhnolohichnoho vykorystannia zerna [Genetic and selection criteria for the creation of varieties of grain crops of alcohol-distillate direction of technological use of grain]. Fyzyolohyia $y$ byokhymyia kult. rastenyi - Physiology and biochemistry cult. plants, 45, 1, 3-20 [in Ukrainian].

14. V Ukraini zareiestrovano hibryd kukurudzy dlia vyrobnytstva bioetanolu [A maize hybrid for bioethanol production has been registered in Ukraine]. URL: https://superagronom.com/news/4996-v-ukrayini-zareyestrovano-gibrid-kukurudzi-dlya-virobnitstva-bioetanolu [in Ukrainian].

15. Lebid, Ye.M., Tsykov, V.S. \& Pashchenko, Yu.M. et al. (2008). Metodyka provedennia polovykh doslidiv z kukurudzoiu [Methods of conducting field experiments with corn]. Dnipropetrovsk [in Ukrainian]. 
16. Stoliarenko, V.S., Ostapenko, L.I. \& Ponchyk, L.I. (2003). Do posivna, pisliazbyralna pidhotovka ta posivni vlastyvosti riznoiakisnoho nasinnia kukurudzy [For sowing, post-harvest preparation and sowing properties of various quality corn seeds]. Biuleten instytutu zernovoho hospodarstva UAAN - Bulletin of the Institute of Grain Management of UAAS, 20, 59-60 [in Ukrainian].

17. HOST 46.045:2003 "Zerno. Metody vyznachennya umovnoyi krokhmalystosti" [GOST 46.045: 2003 "Grain. Methods for determining conditional starch content"] 25.07.2003, 250 [in Ukrainian].

18. Wu, X., Zhao, R., Wang, D., Bean, S., Seib, P.A., Tuinstra, M.R., Campbell, M. \& O'Brien, A. (2006). Effects of amylose amylopectin ratio, corn protein and corn fiber contents on ethanol production. Cereal Chemistry, 83, 5, 569-575 [in English].

19. Blium, Ya.B., Heletukha, H.H., Hryhoriuk, I.P., Dubrovin, V.O., Yemets, A.I., Zabarnyi, H.M., Kaletnik, H.M., Melnychuk, M.D., Myronenko, V.H., Rakhmetov, D.B. \& Tsyhankov, S.P. (2010). Novitni tekhnolohii bioenerhokonversii [The latest technologies of bioenergy conversion]. Kyiv [in Ukrainian].

20. AACC International 2000 (AACCI Method 76-13.01 Total Starch Assay Procedure (Megazyme Amyloglucosidase/ alpha-Amylase Method) [in English].

21. Pashchenko, Yu.M. \& Kordin, O.I. (2010). Vplyv strokiv sivby na urozhainist ta pokaznyky yakosti zerna kukurudzy riznykh hrup styhlosti [Influence of sowing dates on yield and quality of corn grain of different maturity groups]. Khranenye y pererabotka zerna - Storage and processing of grain, 6 (132), 47-48 [in Ukrainian].

22. Pavlov, A.N. (1967). Nakoplenie belka v zerne pshenitsyi i kukuruzyi [Protein accumulation in wheat and maize grains]. Moscow [in Russian].

Паламарчук В.Д., Віннік О.В., Коваленко О.А. Вміст крохмалю у зерні кукурудзи та вихід біоетанолу залежно від умов вегетації та факторів технології вирощування

Мета. Метою статті $€$ вивчення впливу кліматичних умов та елементів технології на продуктивність, якість зерна та вихід біоетанолу в гібридів кукурудзи різних груп стиглості. В дослідженнях застосовувались польовий і лабораторний методи вивчення гібридного матеріалу кукурудзи. Визначення вмісту крохмалю проводили за допомогою поляриметра. Результати. Встановлено, що вміст і вихід крохмалю істотно залежали від групи стиглості гібридів. Так, вміст та вихід крохмалю в ранньостиглій групі склали $72,17 \%$ і 5,797 т/га, середньоранній - 73,05\% і 6,576 т/га, середньостиглій - 74,39\% і 7,666 т/га. Спостерігається зростання вмісту та виходу крохмалю (1,090-1,869 т/га) в групі гібридів кукурудзи із більш тривалим вегетаційним періодом порівняно з ранньостиглою групою. Вміст крохмалю в зерні залежав не лише від групи стиглості гібридів, але й від строків їх сівби. За раннього строку сівби відзначався найменший вміст крохмалю, а за пізнього найбільший. Проведення сівби у ранні строки за рахунок високої врожайності сприяло максимальному виходу крохмалю (7,372 т/га) порівняно із середнім (6,714 т/га) та пізнім (5,953 т/га) строками сівби, тобто застосування пізніх строків сівби сприяло зростанню вмісту та виходу крохмалю на 1,57-1,97\% та 1,181-1,567 т/га відносно раннього строку сівби. Вміст крохмалю може істотно змінюватися залежно від підвиду кукурудзи. Так, за раннього строку сівби вміст крохмалю становив у кременисто-зубовидного підвиду $71,56 \%$, а в зубовидного $73,13 \%$, за середнього строку сівби - $72,44 \%$ та $74,21 \%$, а за пізнього - 73,33\% та 75,06\% відповідно. Висновки. Найвищий вміст крохмалю та його вихід з одиниці площі забезпечило дворазове позакореневе підживлення всіх гібридів мікродобривом Еколист Моно Цинк. Найвищий вихід крохмалю $(0,6-1,9$ т/га) визначено за дворазового позакореневого підживлення мікродобривами Еколист Моно Цинк та Росток кукурудза. Використання мілкої (4-5 см) глибини загортання зерна забезпечило вміст та вихід крохмалю 72,08-75,23\% та 5,9-7,49 т/га, або в середньому 6,75 т/га, середньої (7-8 см) $72,19-76,02 \%$ і $5,85-7,71$ т/га, або в середньому 6,78 т/га, глибокої (10-11 см) - 72,04-75,58\% і 5,68-7,62 т/га, або в середньому 6,66 т/га. Відповідно, найвищий вміст крохмалю у зерні в середньому за три роки склав за глибини загортання 7-8 см, а саме $74,31 \%$, тоді як за глибини загортання $4-5$ см він становив $73,8 \%$, а за глибини $10-11 \mathrm{~cm}-74,11 \%$. Запізнення зі строками сівби гібридів кукурудзи приводить до зменшення виходу біоетанолу на 0,640-0,847 тис. л/га порівняно з раннім строком сівби. Зростання виходу біоетанолу за одноразового позакореневого підживлення становило 0,10-0,65 тис. л/га, а за дворазового позакореневого підживлення - 0,30-1,04 тис. л/га порівняно з контролем (підживлення водою). На орієнтовний вихід біоетанолу впливала фрракція насіння. Зокрема, вихід біоетанолу за сівби насінням дрібної фракції коливався в межах 2,94-3,78 тис. л/га, або в середньому для фрракції 3,41 тис. л/га, за сівби насінням середньої фракції 3,28-4,36 тис. л/га, або в середньому для фракції 3,81, а за сівби насінням великої фракції - 3,33-4,31 тис. л/га, або в середньому для фракції 3,84 тис. л/га. Глибина загортання насіння кукурудзи неоднозначно впливала на вихід біоетанолу із зерна. Так, використання неглибокого (4-5 см) загортання насіння сприяло виходу біоетанолу в межах 3,23-4,11 тис. л/га, або в середньому для цієї глибини 3,697 тис. л/га, за використання середньої (7-8 см) глибини загортання - 3,21-4,23 тис. л/га, або в середньому - 3,713 тис. л/га, а за використання глибокого (10-11 см) загортання - 3,11-4,17 тис. л/га, або в середньому 3,648 тис. л/га, тобто збільшення глибини загортання насіння приводить до зменшення виходу біоетанолу з одиниці посіву.

Ключові слова: кукурудза, крохмаль, біоетанол, фрракція насіння, зерно, позакореневі підживлення, група стиглості.

Palamarchuk V.D., Vinnik O.V., Kovalenko O.A. Starch content in corn grain and bioethanol yield depending on vegetation conditions and factors of cultivation technology

Objective: to study the influence of climatic conditions and elements of technology on productivity, grain quality and bioethanol yield in maize hybrids of different maturity groups. Field and laboratory methods of studying hybrid material of corn were used in the research. Determination of starch content was performed using a polarimeter. Results. The starch content in the grain depended not only on the ripeness group of hybrids, but also on the timing of their sowing. At the early sowing period, the lowest starch content was noted, and at the late sowing period, 
it was noted the highest one. Early sowing, due to the high yield, contributed to the maximum starch yield (7.372 t/ha) compared to the average (6.714 t/ha) and late (5.953 t/ha) sowing periods. That is, the use of late sows periods contributed to an increase in the starch content and yield by $1.57-1.97 \%$ and $1.181-1.567$ t/ha relative to the early sowing period. The starch content can vary significantly depending on the type of corn. Thus, at the early sowing period, the starch content was $71.56 \%$ in the siliceous-tooth - like subspecies, $73.13 \%$; the starch content was in the tooth - like subspecies, 72.44 and $74.21 \%$ in the average sowing period; and the starch content was 73.33 and $75.06 \%$ in the late sowing period. Conclusions. The highest starch content and its yield per unit area were provided by double foliar top dressing of all hybrids with Ecolist Mono zinc microfertilizer. The highest starch yield (0.6-1.9 t/ha) was determined by double foliar top dressing with microfertilizers Ecolist Mono Zinc and Sprout corn. The use of shallow $(4-5 \mathrm{~cm})$ grain embedding depth provided starch content and yield of 72.08 up to $75.23 \%$ and 5.9 up to $7.49 \mathrm{t} / \mathrm{ha}$, or an average of $6.75 \mathrm{t} / \mathrm{ha}$, average $7-8 \mathrm{~cm}$; the starch content and yield was 72.19 up to $76.02 \%$ and 5.85 up to $7.71 \mathrm{t} / \mathrm{ha}$, or an average of $6.78 \mathrm{t} / \mathrm{ha}$; deep $10-11 \mathrm{~cm}$ the starch content and yield was 72.04 up to $75.58 \%$ and $5.68-7.62 \mathrm{t} / \mathrm{ha}$, or an average of $6.66 \mathrm{t} / \mathrm{ha}$. Accordingly, the highest starch content in grain, on average for three years, was $74.31 \%$ at a depth of $7-8 \mathrm{~cm}$, while it was $73.8 \%$ at a depth of $4-5 \mathrm{~cm}$, and it was $74.11 \%$ at a depth of $10-11 \mathrm{~cm}$. The delay in sowing corn hybrids led to a decrease in the yield of bioethanol by 0.640-0.847 thousand liters/ha compared to the early sowing period. The increase in bioethanol yield with a single foliar top dressing was $0.10-0.65$ thousand $1 /$ ha, and with a double foliar top dressing it was $0.30-1.04$ thousand $1 /$ ha compared to the control such as water top dressing. The estimated bioethanol yield was affected by the seed fraction. In particular, the yield of bioethanol for sowing seeds of small fraction, ranged from 2.94-3.78 thousand $1 /$ ha, or on average for the fraction of 3.41 thousand $1 /$ ha, for sowing seeds of medium fraction it was 3.28-4.36 thousand $\mathrm{l} /$ ha or on average for the fraction of 3.81 , and for sowing seeds of large fraction it was 3.33-4.31 thousand $\mathrm{l} / \mathrm{ha}$ or on average for the fraction of 3.84 thousand $\mathrm{I} / \mathrm{ha}$. The depth of embedding of corn seeds had an ambiguous effect on the yield of bioethanol from grain. Thus, the use of nondeep $(4-5 \mathrm{~cm})$ seed embedding contributed to the yield of bioethanol in the range of 3.23 up to 4.11 thousand $\mathrm{I} / \mathrm{ha}$, or on average for this depth of 3.697 thousand $\mathrm{l} / \mathrm{ha}$, for the use of an average $(7-8 \mathrm{~cm})$ depth of embedding it was 3.21 up to 4.23 thousand $\mathrm{l} / \mathrm{ha}$, or on average as 3.713 thousand $\mathrm{l} / \mathrm{ha}$, and for the use of deep $(10-11 \mathrm{~cm})$ embedding it was $3.11-4.17$ thousand. I/ha, or an average of 3.648 thousand $\mathrm{I} / \mathrm{ha}$. That is, an increase in the depth of seed embedding led to a decrease in the yield of bioethanol per unit of sowing.

Key words: corn, starch, bioethanol, seed fraction, grain, foliar top dressing, ripeness group. 